\title{
Highly efficient transfer hydrogenation catalysis with tailored pyridylidene amide pincer ruthenium complexes
}

\author{
Philipp Melle, ${ }^{1}$ Jan Thiede, ${ }^{1}$ Daniela A. Hey, ${ }^{1,2}$ and Martin Albrecht*,1
}

In memoriam Anneke Krüger

\footnotetext{
${ }^{1}$ Department für Chemie und Biochemie, Universität Bern, Freiestrasse 3, CH-3012 Bern, Switzerland.

${ }^{2}$ Fakultät für Chemie, Technische Universität München, Lichtenbergstrasse 4, 85748 Garching, Germany

* email: martin.albrecht@dcb.unibe.ch
}

Key words: ruthenium; pyridylidene amide; ligand design; transfer hydrogenation; high turnover catalysis 


\begin{abstract}
The rational optimization of homogeneous catalysts requires ligand platforms that are easily tailored to improve catalytic performance. Here, we demonstrate that pyridylidene amides (PYAs) provide such a platform to custom-shape transfer hydrogenation catalysts to exceptional activity. Specifically, a series of meta-PYA pincer ligands with differently substituted PYA units has been synthezised and coordinated to ruthenium(II) centres to form bench-stable tris-acetonitrile complexes [Ru(R-PYA-pincer)(MeCN $\left.)_{3}\right]\left(\mathrm{PF}_{6}\right)_{2}$ $\left(\mathrm{R}=\mathrm{OMe}, \mathrm{Me}, \mathrm{H}, \mathrm{Cl}, \mathrm{CF}_{3}\right)$. Analytic studies including ${ }^{1} \mathrm{H}$ NMR spectroscopy, cyclic voltammetry, and $\mathrm{X}$ ray crystallography reveal a direct influence of the substituents on the electronic properties of the ruthenium center. The complexes are active in the catalytic transfer hydrogenation of ketones, with activities directly encoded by the PYA substitution pattern. Their perfomance improves further upon exchange of an ancillary MeCN ligand with $\mathrm{PPh}_{3}$. While complexes [Ru(R-PYA-pincer $\left.)\left(\mathrm{PPh}_{3}\right)(\mathrm{MeCN})_{2}\right]\left(\mathrm{PF}_{6}\right)_{2}$ were only isolated for $\mathrm{R}=\mathrm{H}, \mathrm{Me}$, an in situ protocol was developed to generate these complexes in situ for $\mathrm{R}=\mathrm{OMe}, \mathrm{Cl}, \mathrm{CF}_{3}$ by using a 1:2 ratio of the complexes and $\mathrm{PPh}_{3}$. This in situ protocol together with a short catalyst preactivation provided highly active catalytic systems. The most active pre-catalyst featured the methoxysubstituted PYA ligand and reached turnover frenquencies of $210,000 \mathrm{~h}^{-1}$ under an exceptionally low catalyst loading of $25 \mathrm{ppm}$ for the benchmark substrate benzophenone, representing one of the most active transfer hydrogenation systems known to date.
\end{abstract}

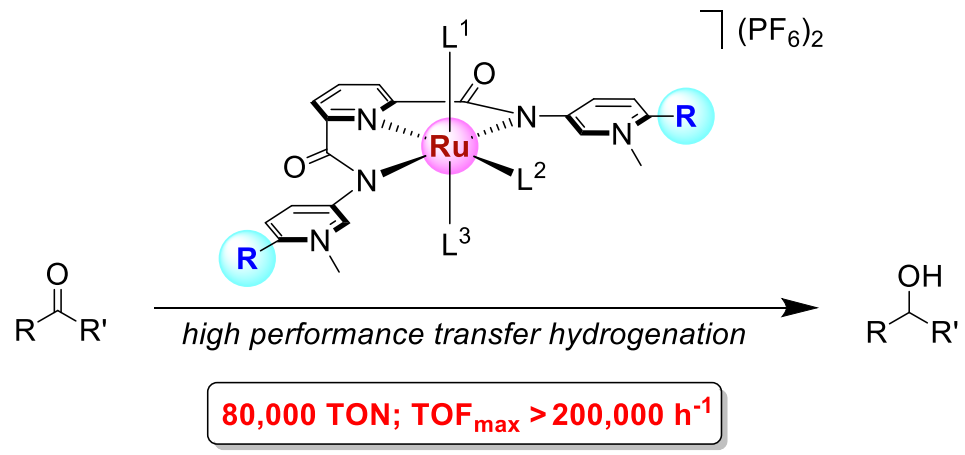




\section{Introduction}

Advanced ligand design has become a key technology to improve homogeneous catalysts. Specifically, the development of cooperative ligands that undergo chemical transformation synergistically with the metal center has enabled numerous transformations with unrivalled efficiency. ${ }^{[1-8]}$ In a complementary approach, considerable progress has been achieved with ligands that feature ambiguous donor properties. $\mathrm{N}$-Heterocyclic carbenes (NHC) may be considered a prime example of this class of donor-ambiguous ligands, as NHCs feature a neutral L-type carbene resonance structure as well as an zwitterionic ylid resonance form, which imparts an anionic X-type metal coordination (A, Fig. 1). ${ }^{[9-12]}$ Although rarely discussed in this context, this donor ambiguity of NHCs may be relevant for the high catalytic activity that these ligands often entail. A growing number of related ligand systems with a similarly ambiguous coordination motif has evolved from this scaffold, including for example mesoionic NHCs, ${ }^{[13,14]}$ and $\mathrm{N}$-heterocyclic olefins $(\mathbf{B}) \cdot{ }^{[15-20]}$ In more recent years, this concept has been expanded from C-donors to $\mathrm{N}$-donor ligands as competitive alternatives to NHCs. ${ }^{[21]}$ In particular Alcarazo-type ligand scaffolds combining a metal-bound imine as part of a guanidine derivative $(\mathbf{C})$, or bound to a benzimidazolylidene or cyclopropenyl scaffold have shown promising donor properties. ${ }^{[22,23]}$ A related ligand class are the so-called pyridylidene amides (PYAs, D) ${ }^{[24]}$ and pyridylidene amines (PYEs) ${ }^{[25-27]}$ which feature a neutral imine resonance structure with L-type metal coordination, as well as a zwitterionic pyridinium amide resonance form. These ligands were demonstrated to adapt their donor properties in response to the external environment, such as solvent polarity, and to the electronic configuration of the metal center, which ensues stabilization of different metal oxidation states. ${ }^{[28-30]}$ As a consequence of these unique and flexible donor properties, PYA ligands have been successfully applied in a variety of catalytic transformations with appealing performances. ${ }^{[28-36]}$

L-type coordination
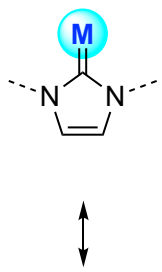

X-type coordination

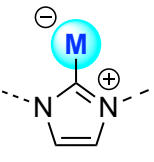

A
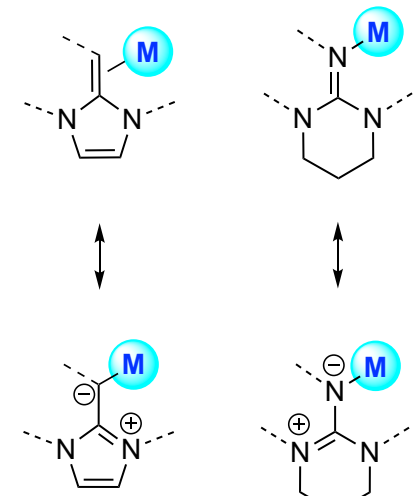

B

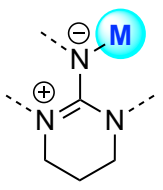

C

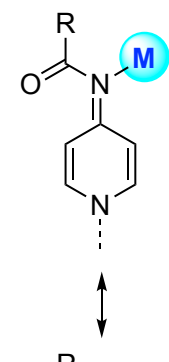

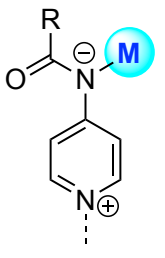

D

Figure 1. Selected ligands that feature ambiguous donor properties. 
PYAs are a particularly attractive sub-class of donor-flexible ligands because of their easy accessibility and their synthetic versatility, which provides ample opportunities for ligand modifications. PYA variation has focused predominantly on modulation of the amide substituent $\mathrm{R}$, including the incorporation of chelating groups, ${ }^{[24,28-30,35,37]}$ as well as the positioning of the pyridinium site. ${ }^{[26,31,34,35]}$ Remarkably, however, the synthetic versatility of pyridines has not been explored so far, even though such modifications are bound to have a direct impact on the donor properties of the PYA ligand. Here, we have introduced substituents on the PYA heterocycle in meta-PYA pincer-type ligands and demonstrate that their electronic influence directly affects the catalytic properties of the coordinated ruthenium center. We have exploited this methodology to develop highly active transfer hydrogenation catalysts, which reach turnover frequencies of more than $200,000 \mathrm{~h}^{-1}$ and operate at unusually low catalyst loadings in the ppm range, thus providing a catalytic system that offers an attractive alternative to other high-performance catalysts.

\section{Results and discussion}

Synthesis of substituted PYA pincer ruthenium complexes. The dicationic ligand salts L1-5 were synthesized according to slightly modified literature procedures ${ }^{[38]}$ starting from 2-substituted 5aminopyridines and 2,6-pyridinedicarbonyl dichloride (Scheme 1). Amidation gave the substituted bis(amides) pre-L1-5 in good 70-90\% yields, ${ }^{[39]}$ and subsequent methylation afforded the ligand precursors L1-5. Successful methlyation required an excess of MeOTf as a strong alkylating reagent rather than MeI, which was used for preparing the unsubstituted meta-PYA pincer ligand L3. ${ }^{[35]}$ With MeI, an inseparable mixture of mono- and bis-alkylated products formed. Anion exchange from $\mathrm{OTf}^{-}$to $\mathrm{PF}_{6}{ }^{-}$was accomplished with an excess of $\mathrm{NH}_{4} \mathrm{PF}_{6}$ in a $\mathrm{MeCN} / \mathrm{H}_{2} \mathrm{O}$ solvent mixture, as indicated by HR ESI-MS analysis through detection of the monocationic ligand species, e.g. $\left[\mathrm{M}-\mathrm{PF}_{6}\right]^{+}$at 554.1387 amu for $\mathbf{L 1}$ (calcd. 554.1386).
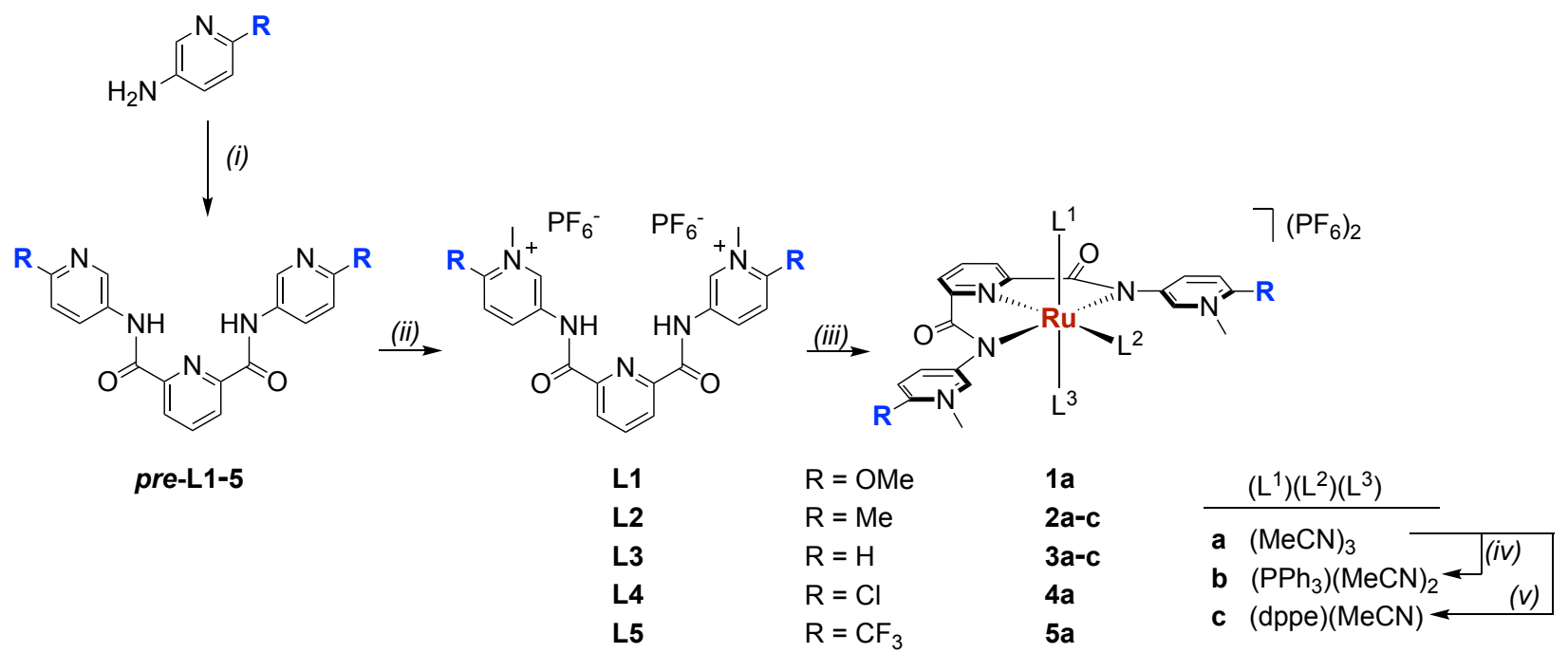

Scheme 1. General synthesis of the para-substituted meta-PYA pincer ligands, complexation to ruthenium, and ancillary ligand exchange. Reagents and conditions: (i) 2 eq. 2,6-pyridinedicarbonyl dichloride, toluene, reflux, $3 \mathrm{~h}$. 
(ii) 3 eq. MeOTf, $\mathrm{CH}_{2} \mathrm{Cl}_{2}$, reflux, 16 h; then 5 eq. $\mathrm{NH}_{4} \mathrm{PF}_{6}, \mathrm{H}_{2} \mathrm{O} / \mathrm{MeCN}$. (iii) 0.5 eq. $\left[\mathrm{RuCl}_{2} \text { (cym) }\right]_{2}, 3$ eq. $\mathrm{Na}_{2} \mathrm{CO}_{3}$, $\mathrm{MeCN}$, reflux, 16 h. (iv) 1.1 eq. $\mathrm{PPh}_{3}$, EtOH, reflux 16 h. (v) 1.1 eq dppe, EtOH, reflux, 16 h.

Ruthenation of the ligand precursors $\mathbf{L 1}-\mathbf{5}$ was carried out with $\left[\mathrm{RuCl}_{2}(\mathrm{cym})\right]_{2}$ under basic conditions (cym $=p$-cymene $)^{[35]}$ and gave the octahedral ruthenium(II) PYA pincer complexes 1a-5a with ancillary MeCN ligands. The crude complexes were purified by conventional column chromatography to give analytically pure orange solids that were bench-stable for several weeks without requiring any protection from air or moisture. Ligand coordination to the $\mathrm{Ru}^{\mathrm{II}}$ center resulted in the loss of the low-field $\mathrm{NH}$ amide proton resonances and in a marked upfield shift of the aromatic $\mathrm{H}_{\text {PYA }}^{6}$ proton resonances, e.g. from $\delta_{\mathrm{H}}=9.26$ in $\mathbf{L 1}$ to 8.49 in complex 1a. The three coordinated $\mathrm{MeCN}$ ligands gave two sets of singlets in 2:1 integral ratio, in agreement with two chemically equivalent axially coordinated $\mathrm{MeCN}$ entities and one equatorial $\mathrm{MeCN}$ coordinated in the PYA pincer plane.

Heating of the tris-acetonitrile complex 2a comprised of a methyl-substituted PYA ligand in an ethanolic solution with a slight excess of $\mathrm{PPh}_{3}$ or dppe (dppe = 1,2-diphenylphosphinoethane) afforded the monophosphine complex $\mathbf{2 b}$ and the dppe analogue $\mathbf{2 c}$, respectively (Scheme 1). Remarkably, all attempts to isolate the phosphine variants of complexes $\mathbf{1}, \mathbf{4}$ or $5\left(\mathrm{R}=\mathrm{OMe}, \mathrm{Cl}, \mathrm{CF}_{3}\right)$ have been unsuccesful thus far. Neither modification of the synthetic procedure such as avoiding protic solvents, nor using lower temperatures or inert atmosphere, nor varying the phosphine equivalents gave the desired complexes. ${ }^{1} \mathrm{H}$ NMR analysis of the crude products showed broad paramagnetic signals and attempts to isolate the formed products only gave insoluble black solids. We speculate that the $\mathrm{Ru}(\mathrm{II})$ complexes undergo a slow irreversible oxidation to form meta-stable $\mathrm{Ru}(\mathrm{III})$ species under the applied conditions.

Spectroscopic, electrochemical, and structural analysis of the impact of the PYA substituents. The electronic impact of the different PYA substituents of complexes 1a-5a was indicated by a direct correlation of the ${ }^{1} \mathrm{H}$ NMR chemical shifts of $\mathrm{H}^{3}$ and $\mathrm{H}^{6}$ of the PYA ligand with the Hammett parameter $\sigma_{\mathrm{p}}$ of the corresponding substituent (Fig. S21, Table 1). ${ }^{[40]}$ For example, the $\mathrm{H}^{3}$ PYA resonance shifts from $\delta_{\mathrm{H}}=7.37$ in complex 1 bearing a methoxy substituent $\left(\sigma_{\mathrm{p}}=-0.27\right)$ downfield to $\delta_{\mathrm{H}}=7.84$ in complex 3a with an unsubstituted meta-PYA ligand $\left(\sigma_{\mathrm{p}}=0\right)$ and to $\delta_{\mathrm{H}}=8.27$ in complex 5a featuring an electron-withdrawing $\mathrm{CF}_{3}$ substituent $\left(\sigma_{\mathrm{p}}=+0.54\right)$. A similar shift range of $\Delta \delta_{\mathrm{H}}=0.76$ was observed for the $\mathrm{H}_{\text {PYA }}^{6}$ resonance, while the $\mathrm{H}_{\text {PYA }}^{4}$ signal was unaffected, presumably due to $\mathrm{H}$-bonding to the amide $\mathrm{C}=\mathrm{O}$ fragment.

Whereas NMR spectroscopic data is limited to probe ligand-based electronic properties, cyclic voltammetry (CV) measurements provide a method to evaluate the electron density at the metal center. Complexes 1a5a show a reversible redox process around $0.5 \mathrm{~V}(v s$ SSCE) and a second, quasi-reversible process around 1.7 V (Fig. 2a, Fig. S22, S23), which have been attributed to $\mathrm{Ru}^{\mathrm{II} / I I I}$ and $\mathrm{Ru}^{\mathrm{III/IV}}$ transitions. The half-wave 
potentials $\left(E_{1 / 2}\right)$ for the $\mathrm{Ru}^{\mathrm{II} / I I I}$ oxidation indicate a direct influence of the substituent $\mathrm{R}$ on the oxidation potentials of complexes 1a-5a. They gradually increase as the PYA substituent becomes less donating from $0.60 \mathrm{~V}$ for $1 \mathrm{a}(\mathrm{R}=\mathrm{OMe})$ to $0.66 \mathrm{~V}$ (complexes $2 \mathrm{a}$ and $\mathbf{3 a}, \mathrm{R}=\mathrm{Me}, \mathrm{H}), 0.68 \mathrm{~V}($ complex $4 \mathbf{a}, \mathrm{R}=\mathrm{Cl}$ ) and to $0.77 \mathrm{~V}$ (complex 5a, $\mathrm{R}=\mathrm{CF}_{3}$ ). The qualitative correlation of the redox potential with the Hammett parameter $\sigma_{\mathrm{p}}$ (Fig. 2b) indicates that the electron density at the metal center is rationally tailored by an appropriate choice of the substituent $\mathrm{R}$ in these PYA pincer ligands, revealing a substantial impact of synthetically simple ligand modifications. Moreover, it is remarkable that the potential window for the $\mathrm{Ru}{ }^{\mathrm{II} / I I}$ process $\left(\Delta \mathrm{E}_{1 / 2}=170 \mathrm{mV}\right.$ between $\mathrm{R}=\mathrm{OMe}$ and $\left.\mathrm{R}=\mathrm{CF}_{3}\right)$ is considerably amplified for the $\mathrm{Ru}^{\mathrm{III} / \mathrm{V}}$ transition $\left(\Delta \mathrm{E}_{1 / 2}\right.$ $=310 \mathrm{mV})$.
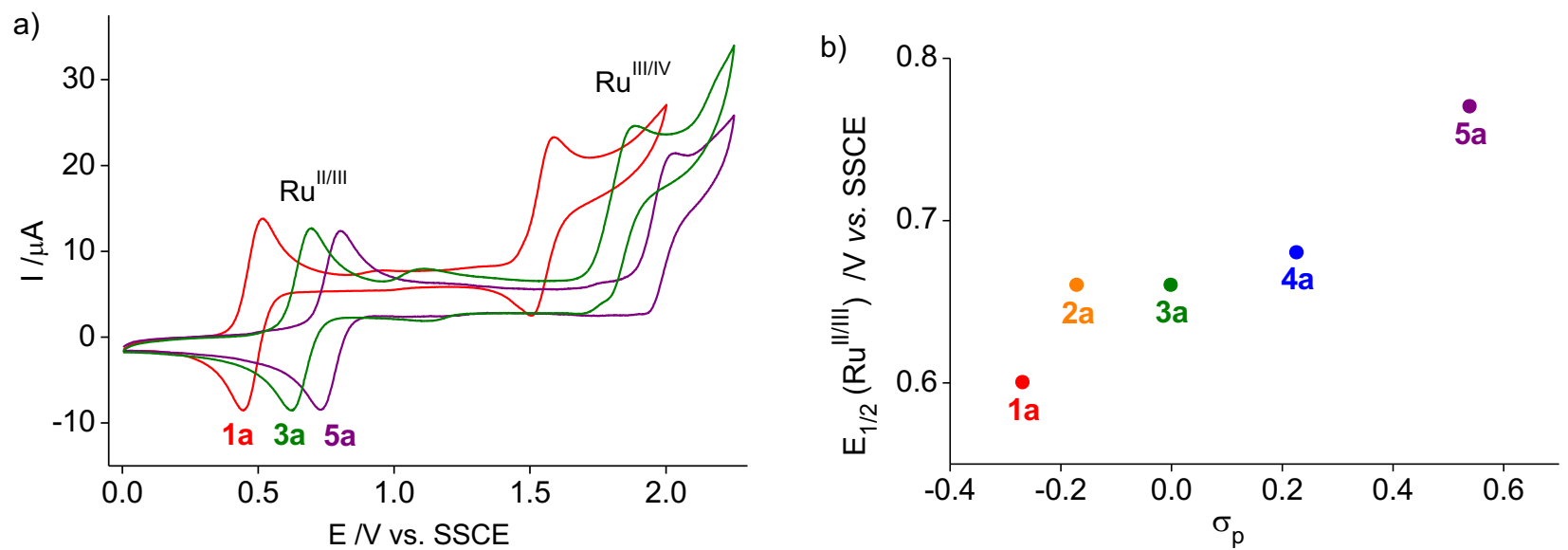

Figure 2. a) Cyclic voltammetry measurements of complexes 1a (red), 3a (green), and 5a (purple) in MeCN (1 mM complex conc., potentials vs. SSCE using the $\mathrm{Fc}^{+} / \mathrm{Fc}$ couple as standard; $\mathrm{E}_{1 / 2}=+0.4319$ and $\mathrm{n}-\mathrm{Bu}_{4} \mathrm{NPF}_{6}$ as electrolyte, $100 \mathrm{mVs}^{-1}$ scan rate). b) Redox potentials vs. $\sigma_{\mathrm{p}}$ for complexes 1a-5a.

Further support for the influence of the ligand system on the complex properties was gained by UV-vis spectroscopy (Fig. S24). The characteristic metal-to-ligand charge transfer (MLCT) bands in the visible region of the spectra (390-420 nm range) shift gradually to lower energy as the R-substituent becomes more electron withdrawing, in agreement with a lower energy of the ligand $\pi^{*}$ MOs and thus a smaller $\mathrm{d}-\pi^{*}$ gap. Low-energy MLCT transitions indicate $\pi$-acidic properties of the PYA ligand and hence a pronounced imine rather than amide resonance form and L-type coordination ( $c f$ Fig. 1) when functionalized with electronwithdrawing $\mathrm{Cl}$ or $\mathrm{CF}_{3}$ substituents. 
Table 1. Selected ${ }^{1} \mathrm{H}$ NMR, UV-vis spectroscopic and electrochemical data for complexes 1a-5a

\begin{tabular}{|c|c|c|c|c|c|c|c|c|c|}
\hline \multirow[t]{2}{*}{ entry } & \multirow[t]{2}{*}{ complex } & \multirow[t]{2}{*}{$\mathrm{R}$} & \multirow[t]{2}{*}{$\left(L^{1}\right)\left(L^{2}\right)\left(L^{3}\right)$} & \multirow[t]{2}{*}{$\sigma_{\mathrm{p}}$} & \multicolumn{2}{|c|}{$\delta[\mathrm{ppm}]^{\mathrm{a}}$} & \multirow[t]{2}{*}{$\lambda_{\max }[\mathrm{nm}]^{\mathrm{b}}$} & \multicolumn{2}{|c|}{$\mathrm{E}_{1 / 2}[\mathrm{~V}]^{\mathrm{c}}$} \\
\hline & & & & & $\mathrm{H}^{3}$ & $\mathrm{H}^{6}$ & & $\mathrm{Ru}^{\mathrm{II} / I I I}$ & $\mathrm{Ru}^{\mathrm{III/IV}}$ \\
\hline 1 & $1 \mathrm{a}$ & $\mathrm{OMe}$ & $(\mathrm{MeCN})_{3}$ & -0.27 & 7.37 & 8.49 & 393 & 0.60 & 1.67 \\
\hline 2 & $2 a$ & $\mathrm{Me}$ & $(\mathrm{MeCN})_{3}$ & -0.17 & 7.70 & 8.83 & 397 & 0.66 & 1.79 \\
\hline 3 & $3 \mathbf{a}$ & $\mathrm{H}$ & $(\mathrm{MeCN})_{3}$ & 0.00 & 7.84 & 8.91 & 402 & 0.66 & 1.81 \\
\hline 4 & $4 a$ & $\mathrm{Cl}$ & $(\mathrm{MeCN})_{3}$ & 0.23 & 7.92 & 9.03 & 405 & 0.68 & 1.83 \\
\hline 5 & $5 a$ & $\mathrm{CF}_{3}$ & $(\mathrm{MeCN})_{3}$ & 0.54 & 8.27 & 9.25 & 416 & 0.77 & 1.98 \\
\hline
\end{tabular}

${ }^{a}$ in $\mathrm{CD}_{3} \mathrm{CN}$ at $298 \mathrm{~K}, 300 \mathrm{MHz}^{\mathrm{b}}$ in MeCN solutions (50-100 $\mu \mathrm{M} \mathrm{Ru}$ complex). ${ }^{\mathrm{c}}$ in MeCN containing $0.1 \mathrm{M}$ $n \mathrm{Bu}_{4} \mathrm{~N}\left(\mathrm{PF}_{6}\right)$ as supporting electrolyte at $100 \mathrm{mV} \mathrm{s}^{-1}$ scan rate, potentials $v s$. SSCE using $\mathrm{Fc}^{+} / \mathrm{Fc}$ as internal standard at $\mathrm{E}_{1 / 2}=+0.4319(\operatorname{ref}[56])$.

Single crystals of complexes 1a and 5a were analyzed by X-ray diffraction. The molecular structures confirmed the octahedral geometry of the $\mathrm{Ru}(\mathrm{II})$ center and the connectivity pattern deduced from solution analysis (Fig. 3). Both structures show meridional coordination of the PYA pincer ligand and bonding of three $\mathrm{MeCN}$ ligands, with very similar bond distances around the metal center, i.e. little structural variation is imparted by the electronic nature of the PYA substituents (Table 2). The PYA pincer bite angle is identical in both complexes $\left(157.13(5)^{\circ}\right.$ and $157.41(7)^{\circ}$ for $\mathbf{1 a}$ and $\mathbf{5 a}$, respectively), and equal to the unsubstituted analogue 3a $\left(157.55(8)^{\circ}\right)$. Notably, the OMe-substituted PYA heterocycles in complex 1a are substantially twisted out of the plane of the central pyridine ring $\left(\theta=45.5^{\circ}\right.$ and $\left.47.9^{\circ}\right)$ compared to complex $\mathbf{3 a}$ with no substituent $\left(\theta=34.9^{\circ} \text { and } 41.8^{\circ}\right)^{[35]}$ and complex 5a featuring $\mathrm{CF}_{3}$ groups $\left(\theta=29.4^{\circ}\right.$ and $\left.42.6^{\circ}\right)$. A larger dihedral angle indicates a low $\pi$ contribution to the $\mathrm{N}_{\mathrm{PYA}}-\mathrm{C}_{\text {pyridyl }}$ bond (N1-C3) and hence only little conjugation between the PYA heterocycle and the metal-bound amide nitrogen. Consequently, the amide nitrogen is predominantly acting as an anionic X-type $N$-donor ligand, a feature that is most pronounced in complex 1a with strongly donating $\mathrm{OMe}$ substituents and least with electron-withdrawing $\mathrm{CF}_{3}$ groups on the PYA unit.
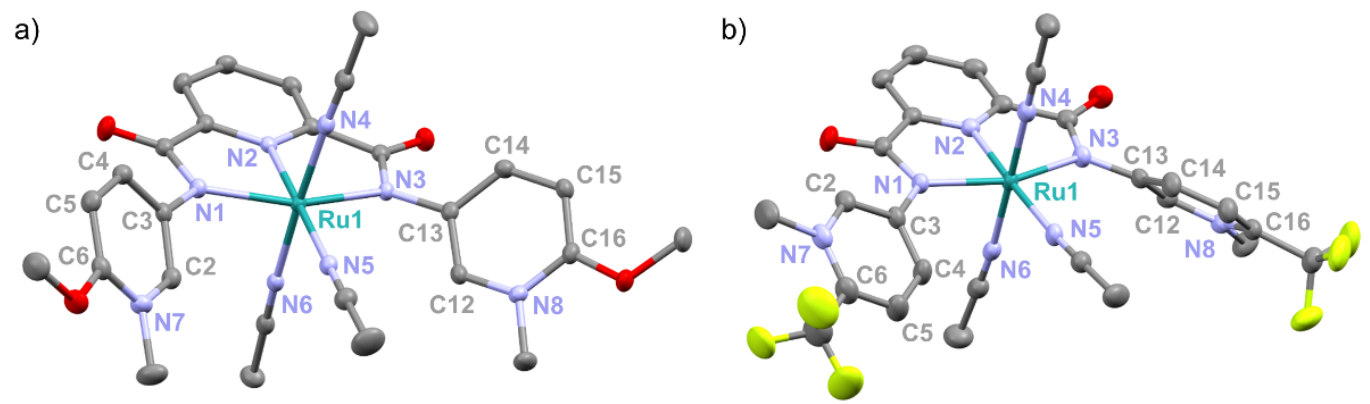
Figure 3. ORTEP representations of the complex cations 1a (a) and 5a (b); all ellipsoids at 50\% probability level (hydrogen atoms, non-coordinating $\mathrm{PF}_{6}^{-}$anions and co-crystallized solvent molecules omitted for clarity).

Table 2. Selected bond lengths $(\AA)$ and angles (deg) for complexes 1a, 3a, and 5a

\begin{tabular}{lccc}
\hline & $\mathbf{1 a}$ & $\mathbf{3 a}^{a}$ & $\mathbf{5 a}$ \\
\hline Ru1-N1 & $2.120(2)$ & $2.106(2)$ & $2.137(2)$ \\
Ru1-N2 & $1.966(1)$ & $1.959(2)$ & $1.964(2)$ \\
Ru1-N3 & $2.108(2)$ & $2.114(2)$ & $2.120(2)$ \\
Ru1-N4 & $2.009(2)$ & $2.024(2)$ & $2.022(2)$ \\
Ru1-N5 & $2.053(1)$ & $2.056(2)$ & $2.051(2)$ \\
Ru1-N6 & $2.015(2)$ & $2.010(2)$ & $2.022(2)$ \\
N1-Ru1-N3 & $157.13(5)$ & $157.55(8)$ & $157.41(7)$ \\
$\theta$ PYA-pyr & $45.5 ; 47.9$ & $34.9 ; 41.8$ & $29.4 ; 42.6$ \\
\hline
\end{tabular}

${ }^{\mathrm{a}}$ from ref [35]. ${ }^{\mathrm{b}}$ dihedral angle $\theta$ between the PYA heterocycle and the $\mathrm{N}-\mathrm{C}=\mathrm{O}$ amide plane.

Transfer hydrogenation catalysis with isolated complexes. All isolated complexes 1a-5a were evaluated as catalyst precursors in transfer hydrogenation of benzophenone as model substrate. Under standard conditions (substrate/base/catalyst in 100:10:1 ratio in refluxing $i \operatorname{PrOH}),{ }^{[41]}$ all reactions went to completion within $1 \mathrm{~h}$ or less. The time-conversion profiles revealed turnover frequencies at $50 \%$ conversion, $\mathrm{TOF}_{50}$, around $500 \mathrm{~h}^{-1}$ for all complexes, though the unsubstituted complex $\mathbf{3 a}$ featured a short induction period (Fig. 4, Table 3).

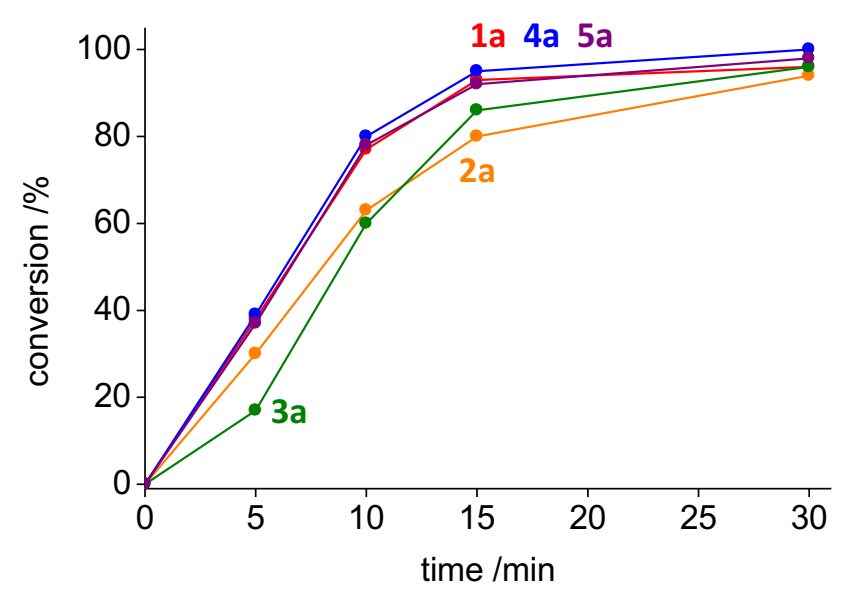

Figure 4. Time-conversion profiles for the transfer hydrogenation of benzophenone with complexes 1a (red), 2a (yellow), 3a (green), 4a (blue) and 5a (purple). Reaction conditions: benzophenone (0.5 mmol), $\mathrm{KOH}(0.05 \mathrm{mmol}$, $10 \mathrm{~mol} \%)$, cat. (0.005 mmol, $1 \mathrm{~mol} \%), i \mathrm{PrOH}(10 \mathrm{ml}), \mathrm{N}_{2}$ atmosphere, reflux temperature. 
Exchange of ancillary MeCN ligands by phosphines further enhanced the catalytic activity and allowed for reducing the catalyst loading to $0.1 \mathrm{~mol} \%$ (entries 6-9). While the MeCN complex 2a gave only slow conversion at this S/B/C ratio of 1000:10:1 (33\% after $0.5 \mathrm{~h}$; Fig. 5), introduction of dppe raised the activity markedly and complex $2 \mathrm{c}$ reached $62 \%$ conversion within this time frame, corresponding to a 2-3 times better performance. Complex $\mathbf{2 b}$ containing an ancillary $\mathrm{PPh}_{3}$ ligand was even more active and reached full conversion within $30 \mathrm{~min}\left(\mathrm{TOF}_{50}\right.$ around $\left.7,000 \mathrm{~h}^{-1}\right)$. This activity is more than one order of magnitude higher than the $\mathrm{MeCN}$ analogue 2a. This result underpins the benefits from combining the donor flexible PYA pincer scaffold with the strong trans effect of phosphine ligands ${ }^{[35,42]}$ for efficient transfer hydrogenation catalysis.

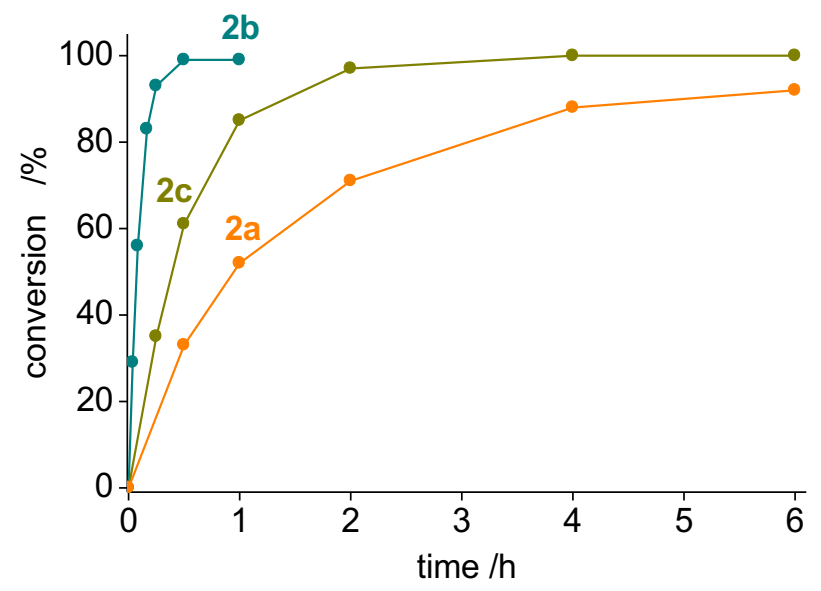

Figure 5. Time-conversion profiles for the transfer hydrogenation of benzophenone with complexes $\mathbf{2 a}$ (orange), $\mathbf{2 b}$ (cyan) and 2c (light green) at $0.1 \mathrm{~mol} \%$ catalyst loading. Reaction conditions: benzophenone (5.0 mmol), $\mathrm{KOH}$ (0.05 mmol, $10 \mathrm{~mol} \%)$, cat. $(0.005 \mathrm{mmol}, 1 \mathrm{~mol} \%), i \operatorname{PrOH}(10 \mathrm{ml}), \mathrm{N}_{2}$ atmosphere, reflux temperature.

Table 3. Catalytic activity of isolated PYA pincer ruthenium complexes in transfer hydrogenation of benzophenone. ${ }^{\mathrm{a}}$

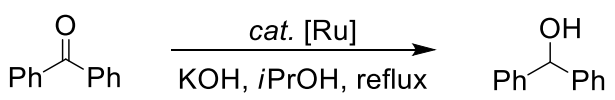

\begin{tabular}{llllcccccc}
\hline entry & {$[\mathrm{Ru}]$} & $\mathrm{R}$ & $\left.\left(\mathrm{L}^{1}\right)\left(\mathrm{L}^{2}\right) \mathrm{L}^{3}\right)$ & loading $[\mathrm{mol} \%]$ & \multicolumn{4}{c}{ conversion $[\%]^{\mathrm{b}}$} & \multicolumn{3}{c}{$\mathrm{TOF}_{50}\left[\mathrm{~h}^{-1}\right]^{\mathrm{c}}$} \\
\cline { 5 - 8 } & & & & & 5 & 15 & 30 & $60 \mathrm{~min}$ & \\
\hline 1 & $\mathbf{1 a}$ & $\mathrm{OMe}$ & $(\mathrm{MeCN})_{3}$ & 1 & 38 & 93 & 96 & $>99$ & 470 \\
2 & $\mathbf{2 a}$ & $\mathrm{Me}$ & $(\mathrm{MeCN})_{3}$ & 1 & 30 & 80 & 94 & $>99$ & 380 \\
3 & $\mathbf{3 a}$ & $\mathrm{H}$ & $(\mathrm{MeCN})_{3}$ & 1 & 17 & 86 & 96 & $>99$ & 340 \\
4 & $\mathbf{4 a}$ & $\mathrm{Cl}$ & $(\mathrm{MeCN})_{3}$ & 1 & 39 & 95 & $>99$ & $>99$ & 480
\end{tabular}




$\begin{array}{rlllcccccc}5 & \mathbf{5 a} & \mathrm{CF}_{3} & (\mathrm{MeCN})_{3} & 1 & 37 & 92 & 98 & >99 & 470 \\ 6 & \mathbf{2 a} & \mathrm{Me} & (\mathrm{MeCN})_{3} & 0.1 & \text { n.d. } & \text { n.d. } & 33 & 92 & 500 \\ 7 & \mathbf{2 b} & \mathrm{Me} & \left(\mathrm{PPh}_{3}\right)(\mathrm{MeCN})_{2} & 0.1 & 56 & 93 & >99 & >99 & 6,900 \\ 8 & \mathbf{2 c} & \mathrm{Me} & (\mathrm{dppe})(\mathrm{MeCN}) & 0.1 & \text { n.d. } & 35 & 61 & >99 & 1,300 \\ 9 & \mathbf{3 b} & \mathrm{H} & \left(\mathrm{PPh}_{3}\right)(\mathrm{MeCN})_{2} & 0.1 & 37 & 77 & 95 & >99 & 4,000\end{array}$

${ }^{a}$ General reaction conditions: benzophenone $(0.5$ or $5.0 \mathrm{mmol}), \mathrm{KOH}(0.05 \mathrm{mmol}),[\mathrm{Ru}]$ cat. $(0.005 \mathrm{mmol}), i \mathrm{PrOH}$ $(10 \mathrm{~mL}), \mathrm{N}_{2}$ atmosphere, reflux temperature. ${ }^{\mathrm{b}}$ Determined by ${ }^{1} \mathrm{H}$ NMR spectroscopy using hexamethylbenzene as internal standard and averaged over two runs (less than $10 \%$ deviation), conversions correspond to yields; n.d. = not determined. ${ }^{c}$ see SI for TOF calculations.

Transfer hydrogenation catalysis with in situ formation of $\mathbf{P P h}_{3}$ complexes. Since all attempts to isolate the phosphine complexes $\left[\mathrm{Ru}(\mathrm{R}-\mathrm{PYA} \text {-pincer })\left(\mathrm{PPh}_{3}\right)(\mathrm{MeCN})_{2}\right]^{2+}$ failed when the PYA unit was substituted with a $\mathrm{OMe}, \mathrm{Cl}$, or $\mathrm{CF}_{3}$ group, an in situ methodology was developed to access complexes $\mathbf{1 b}, \mathbf{4 b}$, and $\mathbf{5 b}$ for catalytic application. Such in situ strategies are widely used in homogeneous catalysis, e.g. in high throughput ligand screening ${ }^{[43-45]}$ or when generating highly unstable catalytic systems. ${ }^{[46,47]}$ The in situ methodology was validated with the tris-MeCN complex 3a and compared with the catalytic activity of the analogous isolated $\mathrm{PPh}_{3}$ complex 3b at a S/B/C ratio of 1000:10:1 (Fig. 6). Thus, a catalytic run with complex 3a in the presence of 2 eq. $\mathrm{PPh}_{3}$ afforded a catalytic profile that is comparable to that of isolated complex $\mathbf{3 b}$ apart from a short induction period, indicated by a mere $9 \%$ conversion after 5 min compared to $37 \%$ with the preformed complex $\mathbf{3 b}$. After this induction period, both catalytic systems showed essentially identical performance. Enhancing the phosphine concentration to 10 eq. gave lower conversion rates than with 2 equivalents. Presumably, competitive metal bonding disfavors substrate coordination and leads to complexes with more than one phosphine ligand, which lowers the catalytic performance ( $c f$ dppe complex 3c and proposed mechanism in Scheme S1). This model is supported by the considerably lower activity when complex $\mathbf{3 b}$ was used in the presence of 10 eq. $\mathrm{PPh}_{3}$. The induction time was effectively suppressed, however, when complex 3a was pre-activated with 2 eq. $\mathrm{PPh}_{3}$ at $70^{\circ} \mathrm{C}$ for $10 \mathrm{~min}$. These conditions reproduced the catalytic performance of the isolated complex $\mathbf{3 b}$ very well and were therefore applied for catalysis with complexes $\mathbf{1 a - 5 a}$ to generate complexes $\mathbf{1 b}-\mathbf{5 b}$ in situ. 


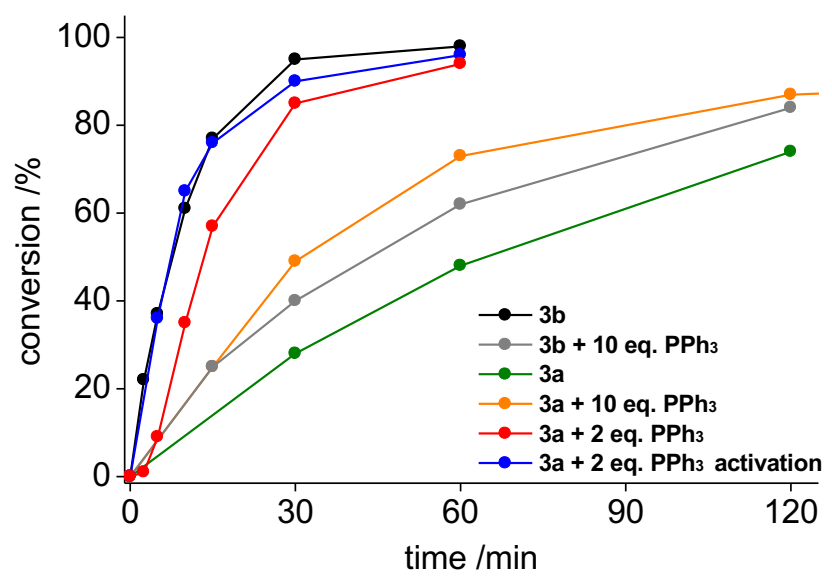

Figure 6. Time-conversion profiles for experiments carried out in order to find the best protocol for the in situ formation of catalyst $\mathbf{3 b}$ starting from 3a. General reaction conditions: benzophenone $(5.0 \mathrm{mmol}), \mathrm{KOH}(0.05 \mathrm{mmol}$, $1 \mathrm{~mol} \%$ ), complex (0.005 mmol, $0.1 \mathrm{~mol} \%), \mathrm{PPh}_{3}$ (varying amounts), $i \operatorname{PrOH}(10 \mathrm{ml}), \mathrm{N}_{2}$ atmosphere, reflux temperature.

All pre-activated and in situ generated complexes $\mathbf{1 b}-\mathbf{5 b}$ are considerably more active than the phosphine-free parent complexes 1a-5a, and although the catalyst loading was reduced tenfold from 1 to $0.1 \mathrm{~mol} \%$, full conversion of benzophenone was achieved in much shorter reaction times than in the absence of $\mathrm{PPh}_{3}$ at higher catalyst loading (Fig. 7, Table 4). For example, full conversion with complex 1a requires more than $30 \mathrm{~min}$ at $1 \mathrm{~mol} \%$ loading in the absence of $\mathrm{PPh}_{3}$ (cf Table 3, entry 1), while the reaction is complete within $5 \mathrm{~min}$ at $0.1 \mathrm{~mol} \%$ loading when 2 eq. $\mathrm{PPh}_{3}$ were added (Table 4, entry 1 ). The activity of this system $\left(\mathrm{TOF}_{\max }\right.$ about $\left.20,000 \mathrm{~h}^{-1}\right)$ is almost two orders of magnitude higher than in the absence of phosphine $\left(\mathrm{TOF}_{\max }\right.$ around $500 \mathrm{~h}^{-1}, c f$ Table 3). Pre-activation enhances the initial activity, though the maximum activity is unaltered (Table S1). Notably, the PYA substituents have a profound effect on the catalytic activity of the phosphine-activated complex. While a Me substituent did not change the activity of the ruthenium center significantly compared to the unsubstituted system, the $\mathrm{CF}_{3}$ group in $\mathbf{5 b}$ induced a twice higher activity, and complexes $\mathbf{1 b}$ and $\mathbf{4 b}$ with $\mathrm{OMe}$ and $\mathrm{Cl}$ substituents, respectively, displayed the highest activity of this series and reached $\mathrm{TOF}_{\max }$ around $20,000 \mathrm{~h}^{-1}$. Obviously, the activity change is not governed solely by the Hammett $\sigma_{\mathrm{p}}$ parameters of the different substituents and instead, other factors like inductive effects may play a significant role for catalytic turnover. 


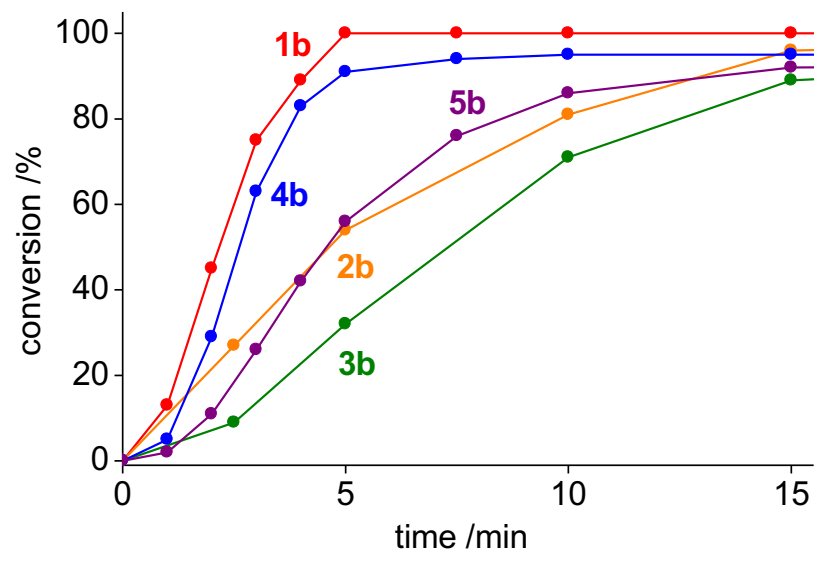

Figure 7. Time-conversion profiles for the transfer hydrogenation of benzophenone with in situ formation of $\mathrm{PPh}_{3}$-complexes after pre-activation of the complex in the presence of 2 moleq. $\mathrm{PPh}_{3}$ for $10 \mathrm{~min}$ at $70^{\circ} \mathrm{C}, \mathbf{1 b}(\mathrm{red}), \mathbf{2 b}$ (yellow), $\mathbf{3 b}$ (green), $\mathbf{4 b}$ (blue) and $\mathbf{5 b}$ (purple). Reaction conditions: benzophenone $(5.0 \mathrm{mmol}), \mathrm{KOH}(0.05 \mathrm{mmol}$, $1 \mathrm{~mol} \%)$, cat. (0.005 mmol, $0.1 \mathrm{~mol} \%), \mathrm{PPh}_{3}(0.01 \mathrm{mmol}, 0.2 \mathrm{~mol} \%) i \operatorname{PrOH}(10 \mathrm{ml}), \mathrm{N}_{2}$ atm., reflux temperature.

Table 4. Catalytic activity in transfer hydrogenation of benzophenone for in situ formed complexes $\mathbf{1 b}-\mathbf{5 b}{ }^{\text {a }}$

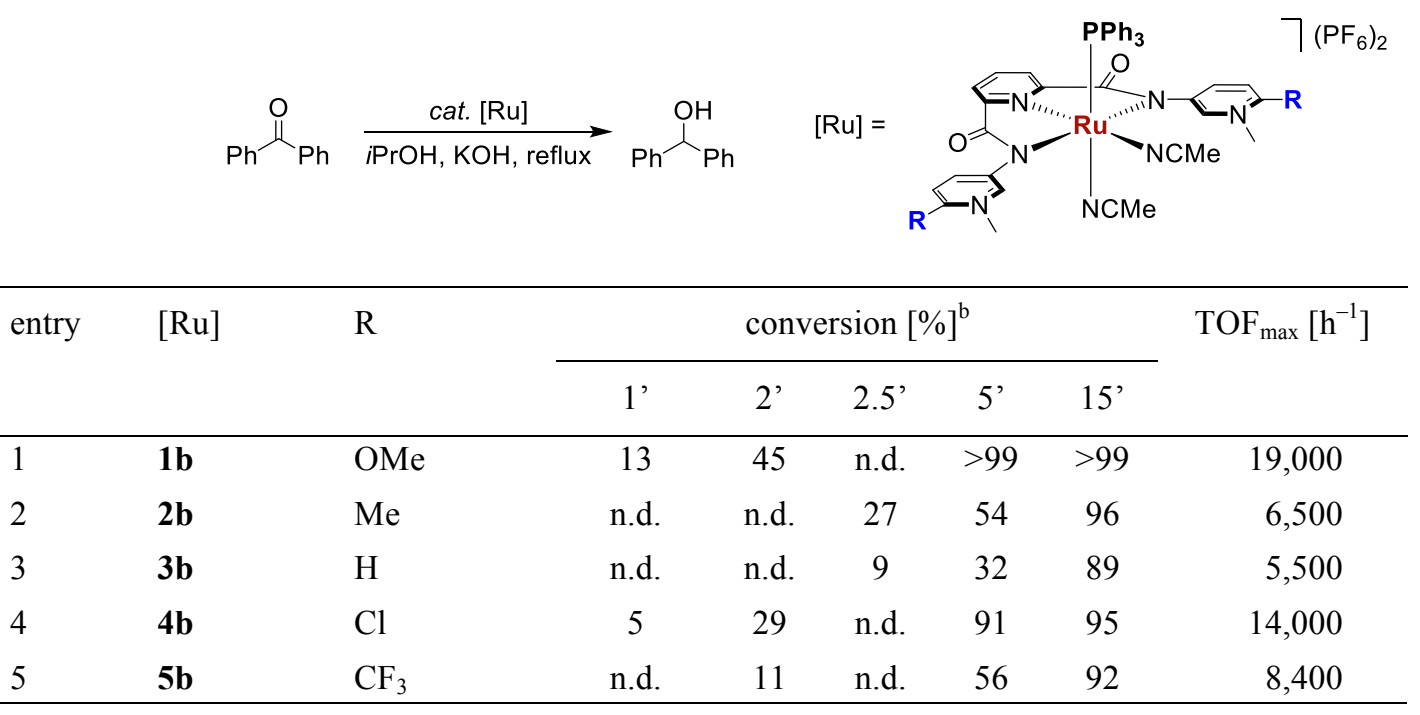

a General reaction conditions: benzophenone $(5.0 \mathrm{mmol})$, complex 1a-5a $(0.005 \mathrm{mmol}, 0.1 \mathrm{~mol} \%), \mathrm{PPh}_{3}$ $(0.01 \mathrm{mmol}, 0.2 \mathrm{~mol} \%) i \operatorname{PrOH}(15 \mathrm{~mL}), \mathrm{N}_{2}$ atmosphere, at $70^{\circ} \mathrm{C}$ for $10 \mathrm{~min}$, then $\mathrm{KOH}(0.05 \mathrm{mmol}, 1 \mathrm{~mol} \%)$, reflux temperature. ${ }^{b}$ Determined by ${ }^{1} \mathrm{H}$ NMR spectroscopy using hexamethylbenzene as internal standard and averaged over two runs (less than $10 \%$ deviation), conversions correspond to yields.

Catalytic transfer hydrogenation with complex 1b. Since complex 1b with OMe-substituted PYA units showed the highest catalytic activity within the series, it was used to optimize catalyst performance (Table 5). Benzophenone was still converted fully within $15 \mathrm{~min}$ when the catalyst loading was lowered by one order of magnitude to $0.01 \mathrm{~mol} \%$ (entry 2). At $0.005 \mathrm{~mol} \%$ catalyst loading full conversion required a twice longer reaction time (entry 3), and the time-conversion profile is almost identical to the reaction with 
$0.01 \mathrm{~mol} \%$ of complex 1 (Fig. S26). Even at $0.0025 \mathrm{~mol} \%$ catalyst loading (25 ppm) essentially full conversion was reached after $2 \mathrm{~h}$ (entry 4). Under these conditions, the $\mathrm{TOF}_{\max }$ was $210,000 \mathrm{~h}^{-1}$, one of the highest activities noted for transfer hydrogenation and comparable to benchmark systems developed by Morris $^{[48]}$ (amine(imine)diphosphine iron complex, TOF $=140,000 \mathrm{~h}^{-1}$ for benzophenone) or Baratta ${ }^{[49]}$ $(\mathrm{RuX}(\mathrm{CO})(\mathrm{dppp})(\mathrm{NN})] \mathrm{Cl}, \mathrm{TOF}=250,000 \mathrm{~h}^{-1}$ for benzophenone). At a $10 \mathrm{ppm}$ catalyst loading (0.001 mol\%), conversion was substantially compromised and incomplete even after prolonging the reaction to $24 \mathrm{~h}$, plateauing at $80 \%$ conversion ( $\mathrm{TON}=80,000$, entry 5 ). The high TONs suggest a remarkable longevity of the catalytically active species, presumably imparted by the tridentate coordinating PYA pincer ligand. Similarly high TONs were reported with related tridentate ligands bound to ruthenium featuring either an S,N,Te-bonding motif $(\mathrm{TON}=96,000)^{[50]}$ or a CNC pincer-type bis(carbene) complex $(\mathrm{TON}=$ 126,000). ${ }^{[51]}$ While attempts to also lower the base concentration from 1 to $0.1 \mathrm{~mol} \% \mathrm{KOH}$ resulted in negligible conversions even after longer reaction times (Fig. S26), the protocol is not restricted to benzophenone and also aliphatic and mixed aryl-alkyl ketones are successfully transfer hydrogenated with the the in situ formed complex 1b (Fig. S27).

Table 5. Catalytic transfer hydrogenation activity of in situ formed complex $\mathbf{1 b}$ towards benzophenone reduction ${ }^{\text {a }}$

\begin{tabular}{cccccc}
\hline entry & $\mathbf{1 b}[\mathrm{mol} \%]$ & time to equilibrium $^{\mathrm{b}}$ & max. conversion $[\%]^{\mathrm{b}}$ & $\mathrm{TOF}_{\max }\left[\mathrm{h}^{-1}\right]$ & final TON $^{\mathrm{b}}$ \\
\hline 1 & 0.1 & $5 \mathrm{~min}$ & $>99$ & 19,000 & $>990$ \\
2 & 0.01 & $15 \mathrm{~min}$ & $>99$ & 90,000 & $>9,900$ \\
3 & 0.005 & $30 \mathrm{~min}$ & $>99$ & 180,000 & $>19,800$ \\
4 & 0.0025 & $2 \mathrm{~h}$ & 98 & 210,000 & 39,200 \\
5 & 0.001 & $24 \mathrm{~h}$ & 80 & 100,000 & 80,000 \\
\hline
\end{tabular}

${ }^{a}$ General reaction conditions: benzophenone (10.0 mmol), cat. 1b (x mol\%), $\mathrm{PPh}_{3}(2 \mathrm{xol} \%) i \operatorname{PrOH}(15 \mathrm{~mL}), \mathrm{N}_{2}$ atmosphere, $70^{\circ} \mathrm{C}$ for $10 \mathrm{~min}$, then $\mathrm{KOH}(0.1 \mathrm{mmol}, 1 \mathrm{~mol} \%)$, reflux temperature. ${ }^{\mathrm{b}}$ Determined by ${ }^{1} \mathrm{H}$ NMR spectroscopy using hexamethylbenzene as internal standard and averaged over two runs (less than $10 \%$ deviation), conversions correspond to yields.

\section{Conclusions}

Here, we demonstrate that modification of the PYA pincer ligand platform with substituents on the PYA fragment provides an efficient methodology for substantially improving ruthenium-catalyzed transfer hydrogenation. The introduction of substituents combined with an in situ protocol for the preparation of phosphine-containing complexes produces highly active systems that surpass the activity of the unsubstituted parent compounds by up to two orders of magnitude, reaching turnover frequencies around $200,000 \mathrm{~h}^{-1}$, which is competitive to other state-of-the-art ruthenium-based catalysts. Moreover, the PYA pincer ruthenium complexes are active even at exceptionally low catalyst loading of $25 \mathrm{ppm}$. The 80,000 
TON achieved with these complexes indicates a long-living catalytically active species. We speculate that the donor flexibility of the PYA ligand is particularly beneficial for accessing several transition states on the catalytic cycle and for stabilizing coordination of both neutral ketone and anioic hydride ligands required for classic monohydride transfer hydrogenation. The high catalyst performance is in line with the demanding requirements for precious metal catalysts and allows them to be used in small quantities only, underlining the potential of suitable ligand tailoring.

\section{Experimental}

General. All reagents were commercially available and used as received. Compounds $\mathbf{L} \mathbf{3}$, and $\mathbf{3 a}-\mathbf{c}$ were synthesized according to previously described procedures. ${ }^{[35]}$ Unless specified otherwise, NMR spectra were recorded at $298 \mathrm{~K}$ on Bruker spectrometers operating at 300 or $400 \mathrm{MHz}\left({ }^{1} \mathrm{H} \mathrm{NMR}\right)$, and $100 \mathrm{MHz}\left({ }^{13} \mathrm{C}\left\{{ }^{1} \mathrm{H}\right\}\right.$ NMR), respectively. Chemical shifts ( $\delta$ in ppm, coupling constants $J$ in Hz) were referenced to residual solvent signals $\left({ }^{1} \mathrm{H},{ }^{13} \mathrm{C}\right)$. Assignments are based on homo- and heteronuclear shift correlation spectroscopy. Purity of bulk samples of the complexes has been established by NMR spectroscopy, and when possible by elemental analysis. Elemental analyses were performed at DCB Microanalytic Laboratory using a Thermo Scientific Flash 2000 CHNS-O elemental analyzer. High-resolution mass spectrometry was carried out with a Thermo Scientific LTQ Orbitrap XL (ESI-TOF) by the mass spectroscopy group of the Department of Chemistry and Biochemistry, University of Bern. UV/Vis measurements were performed on a UV-1800 spectrometer (Shimadzu) with $1 \mathrm{~cm}$ quartz cuvettes. Cyclic voltammograms were recorded using an Autolab PGSTAT101 from Metrohm in MeCN solutions using $10 \mathrm{~mL}$ solvent, $1 \mathrm{mM}$ sample, and $100 \mathrm{mM}$ tetrabutylammonium hexafluorophosphate $\left(n \mathrm{Bu}_{4} \mathrm{~N}\right) \mathrm{PF}_{6}$ as supporting electrolyte. Solutions were degassed with Ar gas for $10 \mathrm{~min}$ prior to each run. The scan rate was $100 \mathrm{mV} \mathrm{s}^{-1}$. Redox potentials were measured using a Pt-button working electrode, an $\mathrm{Ag} / \mathrm{AgCl}$ reference electrode (SSCE) and a Pt-wire auxiliary electrode and are tabulated versus a ferrocene internal standard. The $\mathrm{Fc}^{+} / \mathrm{Fc}$ couple is $0.43 \mathrm{~V}$ vs. SSCE in $0.1 \mathrm{M}\left(n \mathrm{Bu}_{4} \mathrm{~N}\right) \mathrm{PF}_{6} \mathrm{MeCN}$ solutions. ${ }^{[56]}$

General procedure for the synthesis of ligands L1-5. 2-6-Pyridinedicarbonyldichloride (1 eq.) and the corresponding 5-amino-2-substituted-pyridines (2.1-2.5 eq.) were heated to reflux in toluene under vigorous stirring for $3 \mathrm{~h}$. After cooling to room temperature, the formed suspension was filtered and the residue washed with acetone, saturated $\mathrm{NaHCO}_{3}$ solution, water, and again acetone. The resulting solid was dried at $80^{\circ} \mathrm{C}$ and used for the methylation step without further purification. The solid was dissolved in dry $\mathrm{CH}_{2} \mathrm{Cl}_{2}$ under $\mathrm{N}_{2}$ atmosphere and MeOTf (3 eq.) was added carefully. After heating the reaction mixture to reflux for $3-16 \mathrm{~h}$, the reaction mixture was cooled to room temperature and residual MeOTf was quenched by adding $\mathrm{MeOH}(2-3 \mathrm{~mL})$. The resulting precipitate was filtered, washed with small portions of $\mathrm{CH}_{2} \mathrm{Cl}_{2}$ 
and $\mathrm{Et}_{2} \mathrm{O}$, and air dried. This solid was then dissolved in a minimum amount of $\mathrm{MeCN}$, and a solution of $\mathrm{NH}_{4} \mathrm{PF}_{6}$ (5 eq.) in $\mathrm{H}_{2} \mathrm{O}$ (twice the volume of $\mathrm{MeCN}$ ) was added. The formed suspension was heated to reflux until a clear solution formed and then slowly cooled to room temperature, which resulted in the formation of crystals. After cooling to $6^{\circ} \mathrm{C}$ for another $16 \mathrm{~h}$, all crystals were filtered, washed with small portions of cold $\mathrm{H}_{2} \mathrm{O}$, and dried at $80^{\circ} \mathrm{C}$.

Compound L1. According to the general procedure starting from 2,6-pyridinedicarbonyldichloride (818 $\mathrm{mg}, 4 \mathrm{mmol})$ and 5-amino-2-methoxypyridine $(1045 \mathrm{mg}, 8.4 \mathrm{mmol})$ in toluene $(60 \mathrm{~mL})$ giving the bisamide $N^{2}, N^{6}$-bis(6-methoxypyridin-3-yl)pyridine-2,6-dicarboxamide as a purple powder (1208 $\left.\mathrm{mg}, 80 \%\right)$. Refluxing the bis-amide $(1139 \mathrm{mg}, 3.0 \mathrm{mmol})$ in dry $\mathrm{CH}_{2} \mathrm{Cl}_{2}(100 \mathrm{~mL})$ with $\mathrm{MeOTf}(1.0 \mathrm{ml}, 9 \mathrm{mmol})$ for $16 \mathrm{~h}$ gave $\mathbf{L 1}$ as OTf salt (1621 mg, 75\%). Reaction of this triflate salt (354 mg, $0.5 \mathrm{mmol})$ in $\mathrm{MeCN}(6 \mathrm{~mL})$ with aqueous $\mathrm{NH}_{4} \mathrm{PF}_{6}(411 \mathrm{mg}, 2.5 \mathrm{mmol})$ gave $\mathbf{L 1}$ as light purple crystals $(220 \mathrm{mg}, 63 \%)$. ${ }^{1} \mathrm{H} \mathrm{NMR}$ $\left(300 \mathrm{MHz}, \mathrm{CD}_{3} \mathrm{CN}, 298 \mathrm{~K}\right): \delta[\mathrm{ppm}]=10.36\left(\mathrm{~s}, 2 \mathrm{H}, \mathrm{NH}_{\text {amide }}\right), 9.25\left(\mathrm{~d},{ }^{4} J_{\mathrm{HH}}=2.6 \mathrm{~Hz}, 2 \mathrm{H}, \mathrm{H}_{\mathrm{PYA}}\right), 8.68(\mathrm{dd}$, $\left.{ }^{3} J_{\mathrm{HH}}=9.5 \mathrm{~Hz},{ }^{4} J_{\mathrm{HH}}=2.6 \mathrm{~Hz}, 2 \mathrm{H}, \mathrm{H}_{\mathrm{PYA}}\right), 8.50\left(\mathrm{~d},{ }^{3} J_{\mathrm{HH}}=7.8 \mathrm{~Hz}, 2 \mathrm{H}, \mathrm{H}_{\mathrm{pyr}}\right), 8.31\left(\mathrm{t},{ }^{3} J_{\mathrm{HH}}=7.8 \mathrm{~Hz}, 1 \mathrm{H}, \mathrm{H}_{\mathrm{pyr}}\right)$, $7.58\left(\mathrm{~d},{ }^{3} J_{\mathrm{HH}}=9.5 \mathrm{~Hz}, 2 \mathrm{H}, \mathrm{H}_{\mathrm{PYA}}\right), 4.27\left(\mathrm{~s}, 6 \mathrm{H}, \mathrm{NCH}_{3}\right), 4.05\left(\mathrm{~s}, 6 \mathrm{H}, \mathrm{OCH}_{3}\right)$. HR ESI-MS $\left(\mathrm{CH}_{3} \mathrm{CN}\right) \mathrm{m} / z$ calculated for $\left[\mathrm{M}-\mathrm{PF}_{6}\right]^{+}=554.1386$; found: 554.1387. Elemental Analysis: calculated for $\mathrm{C}_{21} \mathrm{H}_{23} \mathrm{~F}_{12} \mathrm{~N}_{5} \mathrm{O}_{4} \mathrm{P}_{2}$ : C: 36.07; H: 3.31; N: 10.01; found: C: 36.37; H: 2.55; N: 9.92.

Compound L2. According to the general procedure starting from 2,6-pyridinedicarbonyldichloride (611 mg, $3 \mathrm{mmol})$ and 5-amino-2-methylpyridine $(811 \mathrm{mg}, 7.5 \mathrm{mmol})$ in toluene $(50 \mathrm{~mL})$ giving the bisamide $N^{2}, N^{6}$-bis(6-methylypyridin-3-yl)pyridine-2,6-dicarboxamide as a purple powder (896 mg, 86\%). Refluxing the bis-amide $(347 \mathrm{mg}, 1.0 \mathrm{mmol})$ in dry $\mathrm{CH}_{2} \mathrm{Cl}_{2}(30 \mathrm{~mL})$ with $\operatorname{MeOTf}(0.33 \mathrm{ml}, 3 \mathrm{mmol})$ for $16 \mathrm{~h}$ gave $\mathbf{L} 2$ as OTf salt (605 mg, 85\%). Reaction of this triflate salt (271 mg, $0.4 \mathrm{mmol})$ in $\mathrm{MeCN}(6 \mathrm{~mL})$, with aqueous $\mathrm{NH}_{4} \mathrm{PF}_{6}(329 \mathrm{mg}, 2.0 \mathrm{mmol})$ gave $\mathbf{L} 2$ as off white crystals (189 mg, 71\%). ${ }^{1} \mathrm{H} \mathrm{NMR} \mathrm{(300} \mathrm{MHz,}$ $\left.\mathrm{CD}_{3} \mathrm{CN}, 298 \mathrm{~K}\right): \delta[\mathrm{ppm}]=10.52\left(\mathrm{~s}, 2 \mathrm{H}, \mathrm{NH}_{\mathrm{amide}}\right), 9.57\left(\mathrm{~d},{ }^{4} J_{\mathrm{HH}}=2.3 \mathrm{~Hz}, 2 \mathrm{H}, \mathrm{H}_{\mathrm{PYA}}\right), 8.63\left(\mathrm{dd},{ }^{3} J_{\mathrm{HH}}=8.8\right.$ $\left.\mathrm{Hz},{ }^{4} J_{\mathrm{HH}}=2.3 \mathrm{~Hz}, 2 \mathrm{H}, \mathrm{H}_{\mathrm{PYA}}\right), 8.53\left(\mathrm{~d},{ }^{3} J_{\mathrm{HH}}=7.7 \mathrm{~Hz}, 2 \mathrm{H}, \mathrm{H}_{\mathrm{pyr}}\right), 8.32\left(\mathrm{t},{ }^{3} J_{\mathrm{HH}}=7.7 \mathrm{~Hz}, 1 \mathrm{H}, \mathrm{H}_{\mathrm{pyr}}\right), 7.91(\mathrm{~d}$, $\left.{ }^{3} J_{\mathrm{HH}}=8.8 \mathrm{~Hz}, 2 \mathrm{H}, \mathrm{H}_{\mathrm{PYA}}\right), 4.24\left(\mathrm{~s}, 6 \mathrm{H}, \mathrm{NCH}_{3}\right), 2.75\left(\mathrm{~s}, 6 \mathrm{H}, \mathrm{CH}_{3}\right)$. HR ESI-MS $\left(\mathrm{CH}_{3} \mathrm{CN}\right) \mathrm{m} / z$ calculated for $\left[\mathrm{M}-\mathrm{PF}_{6}\right]^{+}=522.1488$; found: 522.1484. Elemental Analysis: calculated for $\mathrm{C}_{21} \mathrm{H}_{23} \mathrm{~F}_{12} \mathrm{~N}_{5} \mathrm{O}_{2} \mathrm{P}_{2}$ : C: 37.79 ; $\mathrm{H}$ : 3.47; N: 10.49; found: C: 37.53; H: 3.29; N: 10.10 .

Compound L4. According to the general procedure starting from 2,6-pyridinedicarbonyldichloride (611 mg, $3 \mathrm{mmol})$ and 5-amino-2-chloropyridine $(960 \mathrm{mg}, 7.5 \mathrm{mmol})$ in toluene $(50 \mathrm{~mL})$ giving the bisamide $N^{2}, N^{6}$-bis(6-chloroypyridin-3-yl)pyridine-2,6-dicarboxamide as a white powder (1013 $\left.\mathrm{mg}, 87 \%\right)$. Refluxing the bis-amide $(390 \mathrm{mg}, 1.0 \mathrm{mmol})$ in dry $\mathrm{CH}_{2} \mathrm{Cl}_{2}(30 \mathrm{~mL})$ with $\mathrm{MeOTf}(0.33 \mathrm{ml}, 3 \mathrm{mmol})$ for $16 \mathrm{~h}$ gave $\mathbf{L 4}$ as OTf salt (578 $\mathrm{mg}, 81 \%)$. Reaction of this triflate salt (359 mg, $0.5 \mathrm{mmol})$ in $\mathrm{MeOH}(36 \mathrm{~mL})$ with solid $\mathrm{NH}_{4} \mathrm{PF}_{6}(818 \mathrm{mg}, 5.0 \mathrm{mmol}) \mathbf{L 4}$ as a white powder, which was washed with small portions of 
cold $\mathrm{MeOH}(257 \mathrm{mg}, 74 \%)$. ${ }^{1} \mathrm{H}$ NMR (300 MHz, $\left.\mathrm{CD}_{3} \mathrm{CN}, 298 \mathrm{~K}\right): \delta[\mathrm{ppm}]=10.65$ (s, 2H, $\mathrm{NH}_{\text {amide }}$ ), 9.75 $\left(\mathrm{d},{ }^{4} J_{\mathrm{HH}}=2.5 \mathrm{~Hz}, 2 \mathrm{H}, \mathrm{H}_{\mathrm{PYA}}\right), 8.74\left(\mathrm{dd},{ }^{3} J_{\mathrm{HH}}=9.1 \mathrm{~Hz},{ }^{4} J_{\mathrm{HH}}=2.5 \mathrm{~Hz}, 2 \mathrm{H}, \mathrm{H}_{\mathrm{PYA}}\right), 8.54\left(\mathrm{~d},{ }^{3} J_{\mathrm{HH}}=7.8 \mathrm{~Hz}, 2 \mathrm{H}\right.$, $\left.\mathrm{H}_{\mathrm{pyr}}\right), 8.37-8.32\left(\mathrm{~m}, 1 \mathrm{H}, \mathrm{H}_{\mathrm{pyr}}\right), 8.15\left(\mathrm{~d},{ }^{3} J_{\mathrm{HH}}=9.1 \mathrm{~Hz}, 2 \mathrm{H}, \mathrm{H}_{\mathrm{PYA}}\right), 4.39\left(\mathrm{~s}, 6 \mathrm{H}, \mathrm{NCH}_{3}\right) . \mathrm{HR}$ ESI-MS $\left(\mathrm{CH}_{3} \mathrm{CN}\right)$ $m / z$ calculated for $\left[\mathrm{M}-\mathrm{PF}_{6}\right]^{+}=562.0396$; found: 562.0406. Elemental Analysis: calculated for $\mathrm{C}_{21} \mathrm{H}_{17} \mathrm{Cl}_{2} \mathrm{~F}_{12} \mathrm{~N}_{5} \mathrm{O}_{2} \mathrm{P}_{2}$ : C: $32.22 ; \mathrm{H}: 2.42 ; \mathrm{N}: 9.89$; found: C: 32.29; H: 3.03; N: 9.65 .

Compound L5. According to the general procedure starting from 2,6-pyridinedicarbonyldichloride (310 $\mathrm{mg}, 1.5 \mathrm{mmol})$ and 5-amino-2-trifluoromethylpyridine $(570 \mathrm{mg}, 3.5 \mathrm{mmol})$ in toluene $(25 \mathrm{~mL})$ giving the bis-amide $N^{2}, N^{6}$-bis(6-trifluoromethylpyridin-3-yl)pyridine-2,6-dicarboxamide as a white powder (450 mg, 72\%). Refluxing the bis-amide (300 mg, $0.66 \mathrm{mmol})$ in dry $\mathrm{CH}_{2} \mathrm{Cl}_{2}(40 \mathrm{~mL})$ with $\mathrm{MeOTf}(0.22$ $\mathrm{ml}, 2 \mathrm{mmol}$ ) for $16 \mathrm{~h}$ gave $\mathbf{L 5}$ as OTf salt (479 mg, 93\%). Reaction of this triflate salt (473 $\mathrm{mg}, 0.6 \mathrm{mmol}$ ) in $\mathrm{MeCN}\left(8 \mathrm{~mL}\right.$ ) with aqueous $\mathrm{NH}_{4} \mathrm{PF}_{6}(489 \mathrm{mg}, 3.0 \mathrm{mmol}$ ) gave $\mathbf{L 5}$ as white needle-like crystals (415 mg, 89\%). ${ }^{1} \mathrm{H}$ NMR (300 MHz, $\left.\mathrm{CD}_{3} \mathrm{CN}, 298 \mathrm{~K}\right): \delta[\mathrm{ppm}]=10.86\left(\mathrm{~s}, 2 \mathrm{H}, \mathrm{NH}_{\text {amide }}\right), 9.86\left(\mathrm{~d},{ }^{4} J_{\mathrm{HH}}=2.3 \mathrm{~Hz}, 2 \mathrm{H}\right.$, $\left.\mathrm{H}_{\mathrm{PYA}}\right), 8.98\left(\mathrm{dd},{ }^{3} J_{\mathrm{HH}}=8.9 \mathrm{~Hz},{ }^{4} J_{\mathrm{HH}}=2.3 \mathrm{~Hz}, 2 \mathrm{H}, \mathrm{H}_{\mathrm{PYA}}\right), 8.59\left(\mathrm{~d},{ }^{3} J_{\mathrm{HH}}=7.8 \mathrm{~Hz}, 2 \mathrm{H}, \mathrm{H}_{\mathrm{pyr}}\right), 8.50\left(\mathrm{~d},{ }^{3} J_{\mathrm{HH}}=\right.$ $\left.8.9 \mathrm{~Hz}, 2 \mathrm{H}, \mathrm{H}_{\mathrm{PYA}}\right), 8.38\left(\mathrm{t},{ }^{3} J_{\mathrm{HH}}=7.8 \mathrm{~Hz}, 1 \mathrm{H}, \mathrm{H}_{\mathrm{pyr}}\right), 4.55\left(\mathrm{~s}, 6 \mathrm{H}, \mathrm{NCH}_{3}\right)$. HR ESI-MS $\left(\mathrm{CH}_{3} \mathrm{CN}\right) \mathrm{m} / z$ calculated for $\left[\mathrm{M}-\mathrm{PF}_{6}\right]^{+}=630.0923$; found: 630.0910. Elemental Analysis: calculated for $\mathrm{C}_{21} \mathrm{H}_{17} \mathrm{Cl}_{2} \mathrm{~F}_{12} \mathrm{~N}_{5} \mathrm{O}_{2} \mathrm{P}_{2}$ : C: 32.53; H: 2.21; N: 9.03; found: C: 32.59; H: 1.79; N: 9.01 .

General procedure for the synthesis of complexes 1a-5a. The ligand L1-L5 (1 eq.), $\left[\mathrm{RuCl}_{2} \text { (cym) }\right]_{2}\left(0.5\right.$ eq.) and $\mathrm{Na}_{2} \mathrm{CO}_{3}$ (3 eq.) were dissolved in $\mathrm{MeCN}$ and heated to reflux for $16 \mathrm{~h}$. The reaction mixture was cooled to $-18{ }^{\circ} \mathrm{C}$ for $2 \mathrm{~h}$ for quantitative precipitation, then filtered over Celite and the filtrate was concentrated to a saturated solution under reduced pressure. The crude product was precipitated from $\mathrm{Et}_{2} \mathrm{O}$, filtered, washed with $\mathrm{Et}_{2} \mathrm{O}$, and purified by gradient column chromatography.

Complex 1a. According to the general procedure starting from L1 (595 $\mathrm{mg}, 0.85 \mathrm{mmol}$ ), $\left[\mathrm{RuCl}_{2}(\mathrm{cym})\right]_{2}(260 \mathrm{mg}, 0.43 \mathrm{mmol})$ and $\mathrm{Na}_{2} \mathrm{CO}_{3}(274 \mathrm{mg}, 2.55 \mathrm{mmol})$ in $\mathrm{MeCN}(180 \mathrm{~mL})$. Purification by gradient column chromatography $\left(\mathrm{Al}_{2} \mathrm{O}_{3} ; \mathrm{CH}_{2} \mathrm{Cl}_{2} / \mathrm{MeCN}\right.$ 1:1 to pure $\left.\mathrm{MeCN}\right)$ gave 1a as dark orange powder (296 mg, 38\%). ${ }^{1} \mathrm{H}$ NMR (300 MHz, $\left.\mathrm{CD}_{3} \mathrm{CN}, 298 \mathrm{~K}\right): \delta[\mathrm{ppm}]=8.49\left(\mathrm{~d},{ }^{4} J_{\mathrm{HH}}=2.5 \mathrm{~Hz}, 2 \mathrm{H}, \mathrm{H}_{\mathrm{PYA}}\right), 8.44$ $\left(\mathrm{dd},{ }^{3} J_{\mathrm{HH}}=9.3 \mathrm{~Hz},{ }^{4} J_{\mathrm{HH}}=2.5 \mathrm{~Hz}, 2 \mathrm{H}, \mathrm{H}_{\mathrm{PYA}}\right), 8.04-8.00\left(\mathrm{~m}, 3 \mathrm{H}, \mathrm{H}_{\mathrm{pyr}}\right), 7.37\left(\mathrm{~d},{ }^{3} J_{\mathrm{HH}}=9.3 \mathrm{~Hz}, 2 \mathrm{H}, \mathrm{H}_{\mathrm{PYA}}\right)$, $4.21\left(\mathrm{~s}, 6 \mathrm{H}, \mathrm{NCH}_{3}\right), 3.99$ (s, 6H, $\left.\mathrm{OCH}_{3}\right), 2.48\left(\mathrm{~s}, 3 \mathrm{H}, \mathrm{H}_{\mathrm{MeCN}(\text { equ })}\right), 2.13$ (s, 6H, $\left.\mathrm{H}_{\mathrm{MeCN}(\text { axial })}\right) .{ }^{13} \mathrm{C}\left\{{ }^{1} \mathrm{H}\right\} \mathrm{NMR}(75$ $\left.\mathrm{MHz}, \mathrm{CD}_{3} \mathrm{CN}, 298 \mathrm{~K}\right): \delta[\mathrm{ppm}]=170.73(\mathrm{C}=\mathrm{O}), 158.09\left(\mathrm{C}_{\mathrm{pyr}}\right), 156.43\left(\mathrm{C}_{\mathrm{pyr}}\right), 146.66\left(\mathrm{CH}_{\mathrm{pyr}}\right), 143.95\left(\mathrm{C}_{\mathrm{pyr}}\right)$, $139.55\left(\mathrm{CH}_{\mathrm{pyr}}\right), 136.82\left(\mathrm{CH}_{\mathrm{pyr}}\right), 128.20(\mathrm{NCMe}), 125.81\left(\mathrm{CH}_{\mathrm{pyr}}\right), 124.37(\mathrm{NCMe}), 110.12\left(\mathrm{CH}_{\mathrm{pyr}}\right), 59.64$ $\left(\mathrm{O}-\mathrm{CH}_{3}\right), 42.48\left(\mathrm{~N}-\mathrm{CH}_{3}\right), 4.47\left(\mathrm{NCCH}_{3}\right), 4.11\left(\mathrm{NCCH}_{3}\right)$. HR ESI-MS $\left(\mathrm{CH}_{3} \mathrm{CN}\right) \mathrm{m} / z$ calculated for [M$\left.\mathrm{PF}_{6}-\mathrm{MeCN}\right]^{+}=736.08043$; found: 736.0809. Elemental Analysis: calculated for $\mathrm{C}_{27} \mathrm{H}_{30} \mathrm{~F}_{12} \mathrm{~N}_{8} \mathrm{O}_{4} \mathrm{P}_{2} \mathrm{Ru}$ : $\mathrm{C}$ : 35.19; H: 3.28; N: 12.16; found: C: 35.06; H: 3.51; N: 12.09 . 
Complex 2a. According to the general procedure starting from $\mathbf{L 2}$ (154 $\mathrm{mg}, 0.24 \mathrm{mmol}$ ), $\left[\mathrm{RuCl}_{2}(\mathrm{cym})\right]_{2}(71 \mathrm{mg}, 0.12 \mathrm{mmol})$ and $\mathrm{Na}_{2} \mathrm{CO}_{3}(74 \mathrm{mg}, 0.69 \mathrm{mmol})$ in $\mathrm{MeCN}(50 \mathrm{~mL})$. No column chromatography was needed. Complex 2a was isolated as dark orange powder (170 mg, 83\%). ${ }^{1} \mathrm{H}$ NMR $\left(300 \mathrm{MHz}, \mathrm{CD}_{3} \mathrm{CN}, 298 \mathrm{~K}\right): \delta[\mathrm{ppm}]=8.83\left(\mathrm{~d},{ }^{4} J_{\mathrm{HH}}=2.2 \mathrm{~Hz}, 2 \mathrm{H}, \mathrm{H}_{\mathrm{PYA}}\right), 8.32\left(\mathrm{dd},{ }^{3} J_{\mathrm{HH}}=8.7 \mathrm{~Hz},{ }^{4} J_{\mathrm{HH}}=\right.$ $\left.2.5 \mathrm{~Hz}, 2 \mathrm{H}, \mathrm{H}_{\mathrm{PYA}}\right), 8.08-8.03$ (m, 3H, $\mathrm{H}_{\mathrm{pyr}}$ ), 7.69 (d, $\left.{ }^{3} J_{\mathrm{HH}}=8.7 \mathrm{~Hz}, 2 \mathrm{H}, \mathrm{H}_{\mathrm{PYA}}\right), 4.15$ (s, 6H, NCH $), 2.67$ (s, $\left.6 \mathrm{H}, \mathrm{CH}_{3}\right), 2.47$ (s, 3H, $\left.\mathrm{H}_{\mathrm{MeCN}(\text { equ })}\right), 2.13$ (s, 6H, $\mathrm{H}_{\mathrm{MeCN}(\text { axial) }) .}{ }^{13} \mathrm{C}\left\{{ }^{1} \mathrm{H}\right\} \mathrm{NMR}\left(75 \mathrm{MHz}, \mathrm{CD}_{3} \mathrm{CN}, 298 \mathrm{~K}\right)$ : $\delta[\mathrm{ppm}]=170.95(\mathrm{C}=\mathrm{O}), 157.90\left(\mathrm{C}_{\mathrm{pyr}}\right), 150.06\left(\mathrm{C}_{\mathrm{pyr}}\right), 148.27\left(\mathrm{C}_{\mathrm{pyr}}\right), 143.21\left(\mathrm{CH}_{\mathrm{pyr}}\right), 142.72\left(\mathrm{CH}_{\mathrm{pyr}}\right), 136.96$ $\left(\mathrm{CH}_{\mathrm{pyr}}\right), 129.04\left(\mathrm{CH}_{\mathrm{pyr}}\right), 128.37(\mathrm{NCMe}), 126.20\left(\mathrm{CH}_{\mathrm{pyr}}\right), 124.62(\mathrm{NCMe}), 46.69\left(\mathrm{~N}-\mathrm{CH}_{3}\right), 19.87\left(\mathrm{C}_{\mathrm{PYA}^{-}}\right.$ $\left.\mathrm{CH}_{3}\right), 4.51\left(\mathrm{NCCH}_{3}\right), 4.10\left(\mathrm{NCCH}_{3}\right)$. HR ESI-MS $\left(\mathrm{CH}_{3} \mathrm{CN}\right) \mathrm{m} / z$ calculated for $\left[\mathrm{M}-\mathrm{PF}_{6}-\mathrm{MeCN}\right]^{+}=$ 704.0906; found: 704.0936. Elemental Analysis: calculated for $\mathrm{C}_{27} \mathrm{H}_{30} \mathrm{~F}_{12} \mathrm{~N}_{8} \mathrm{O}_{2} \mathrm{P}_{2} \mathrm{Ru} \times 0.25 \mathrm{CH}_{2} \mathrm{Cl}_{2}$ : $\mathrm{C}$ : 35.93; H: 3.38; N: 12.30; found: C: 35.79; H: 3.90; N: 12.31 .

Complex 2b. To a solution of 2a (152 mg, $0.17 \mathrm{mmol})$ in EtOH $(100 \mathrm{~mL})$ was added $\mathrm{PPh}_{3}(52 \mathrm{mg}$, $0.19 \mathrm{mmol}$ ) and the mixture was heated to reflux for $16 \mathrm{~h}$. After cooling to RT, the solvent was removed under reduced pressure and the crude product was redissolved in a minimum amount of $\mathrm{MeCN}$ and precipitated from $\mathrm{Et}_{2} \mathrm{O}$, filtered, and washed with copious amounts of $\mathrm{Et}_{2} \mathrm{O}$. The residue was purified by gradient column chromatography $\left(\mathrm{Al}_{2} \mathrm{O}_{3}, \mathrm{CH}_{2} \mathrm{Cl}_{2} / \mathrm{MeCN}\right.$ 1:1 to pure $\left.\mathrm{MeCN}\right)$ to yield complex $\mathbf{2 b}$ as an orange powder (102 mg, 54\%). ${ }^{1} \mathrm{H}$ NMR (300 MHz, $\left.298 \mathrm{~K}\right): \delta[\mathrm{ppm}]=8.24\left(\mathrm{~d},{ }^{4} J_{\mathrm{HH}}=2.2 \mathrm{~Hz}, 2 \mathrm{H}, \mathrm{H}_{\mathrm{PYA}}\right)$, $8.13\left(\mathrm{dd},{ }^{3} J_{\mathrm{HH}}=8.5 \mathrm{~Hz},{ }^{4} J_{\mathrm{HH}}=2.2 \mathrm{~Hz}, 2 \mathrm{H}, \mathrm{H}_{\mathrm{PYA}}\right), 7.75\left(\mathrm{t},{ }^{3} J_{\mathrm{HH}}=7.7 \mathrm{~Hz}, 1 \mathrm{H}, \mathrm{H}_{\mathrm{pyr}}\right), 7.75\left(\mathrm{~d},{ }^{3} J_{\mathrm{HH}}=8.5 \mathrm{~Hz}\right.$, $\left.2 \mathrm{H}, \mathrm{H}_{\mathrm{PYA}}\right), 7.58\left(\mathrm{~d},{ }^{3} J_{\mathrm{HH}}=7.7 \mathrm{~Hz}, 2 \mathrm{H}, \mathrm{H}_{\mathrm{pyr}}\right), 7.29-7.24\left(\mathrm{~m}, 3 \mathrm{H}, \mathrm{H}_{\mathrm{PPh} 3}\right), 7.03-6.99\left(\mathrm{~m}, 6 \mathrm{H}, \mathrm{H}_{\mathrm{PPh} 3}\right), 6.95-6.90$ (m, 6H, $\left.\mathrm{H}_{\mathrm{PPh} 3}\right), 4.00\left(\mathrm{~s}, 6 \mathrm{H}, \mathrm{NCH}_{3}\right), 2.72\left(\mathrm{~s}, 6 \mathrm{H}, \mathrm{CH}_{3}\right), 2.58$ (s, 3H, $\left.\mathrm{H}_{\mathrm{MeCN}(\text { equ) }}\right), 2.12$ (s, 3H, $\mathrm{H}_{\mathrm{MeCN}(\text { axial })}$ ). ${ }^{13} \mathrm{C}\left\{{ }^{1} \mathrm{H}\right\}$ NMR $\left(75 \mathrm{MHz}, \mathrm{CD}_{3} \mathrm{CN}, 298 \mathrm{~K}\right): \delta[\mathrm{ppm}]=170.14(\mathrm{C}=\mathrm{O}), 156.30\left(\mathrm{C}_{\text {pyr }}\right), 150.07\left(\mathrm{C}_{\text {PYA }}\right), 148.37$ $\left(\mathrm{C}_{\mathrm{PYA}}\right), 144.15\left(\mathrm{CH}_{\mathrm{PYA}}\right), 142.97\left(\mathrm{CH}_{\mathrm{PYA}}\right), 136.76\left(\mathrm{CH}_{\mathrm{pyr}}\right), 133.45\left(\mathrm{~d},{ }^{2} J_{\mathrm{CP}}=9.9 \mathrm{~Hz}, \mathrm{CH}_{\mathrm{PPh} 3}\right), 132.61\left(\mathrm{~d},{ }^{1} J_{\mathrm{CP}}\right.$ $\left.=44 \mathrm{~Hz}, \mathrm{C}_{\mathrm{PPh} 3}\right), 130.66\left(\mathrm{~d},{ }^{4} J_{\mathrm{CP}}=2.2 \mathrm{~Hz}, \mathrm{CH}_{\mathrm{PPh} 3}\right), 129.25\left(\mathrm{CH}_{\mathrm{PYA}}\right), 128.98\left(\mathrm{~d},{ }^{3} J_{\mathrm{CP}}=9.3 \mathrm{~Hz}, \mathrm{CH}_{\mathrm{PPh} 3}\right), 126.61$ $\left(\mathrm{CH}_{\mathrm{pyr}}\right), 46.51\left(\mathrm{~N}-\mathrm{CH}_{3}\right), 19.97\left(\mathrm{C}_{\mathrm{PYA}}-\mathrm{CH}_{3}\right), 5.24\left(\mathrm{NCCH}_{3}\right) .{ }^{31} \mathrm{P}\left\{{ }^{1} \mathrm{H}\right\} \mathrm{NMR}\left(162 \mathrm{MHz}, \mathrm{CD}_{3} \mathrm{CN}, 298 \mathrm{~K}\right): \delta$ $[\mathrm{ppm}]=51.86\left(\mathrm{~s}, 1 \mathrm{P}, \mathrm{PPh}_{3}\right),-144.59\left(\right.$ septett, $\left.{ }^{1} \mathrm{~J}_{\mathrm{PF}}=709 \mathrm{~Hz}, 2 \mathrm{P}, \mathrm{PF}_{6}\right)$. HR ESI-MS $\left(\mathrm{CH}_{3} \mathrm{CN}\right) \mathrm{m} / z$ calculated for $\left[\mathrm{M}-\mathrm{PF}_{6}-2 \mathrm{MeCN}\right]^{+}=884.1286$; found: 884.1320. Elemental Analysis: calculated for $\mathrm{C}_{43} \mathrm{H}_{42} \mathrm{~F}_{12} \mathrm{~N}_{7} \mathrm{O}_{2} \mathrm{P}_{3} \mathrm{Ru} \times \mathrm{CH}_{2} \mathrm{Cl}_{2}: \mathrm{C}: 44.20 ; \mathrm{H}: 3.71 ; \mathrm{N}: 8.20$; found: $\mathrm{C}: 43.92 ; \mathrm{H}: 3.42 ; \mathrm{N}: 8.06$.

Complex 2c. To a solution of 2a (155 mg, $0.18 \mathrm{mmol})$ in EtOH $(100 \mathrm{~mL})$ was added dppe $(80 \mathrm{mg}$, $0.20 \mathrm{mmol})$ in EtOH $(100 \mathrm{ml})$ and the mixture was stirred at reflux for $16 \mathrm{~h}$. After cooling to RT, the solvent was removed under reduced pressure and the crude product was redissolved in a minimum amount of $\mathrm{MeCN}$ and precipitated from $\mathrm{Et}_{2} \mathrm{O}$, filtered, and washed with copious amounts of $\mathrm{Et}_{2} \mathrm{O}$. The residue was purified by gradient column chromatography $\left(\mathrm{Al}_{2} \mathrm{O}_{3} ; \mathrm{CH}_{2} \mathrm{Cl}_{2} / \mathrm{MeCN}\right.$ 1:1 to pure $\left.\mathrm{MeCN}\right)$ to yield complex $\mathbf{2 c}$ as an orange powder (100 mg, 49\%). ${ }^{1} \mathrm{H}$ NMR $\left(300 \mathrm{MHz}, \mathrm{CD}_{3} \mathrm{CN}, 298 \mathrm{~K}\right): \delta[\mathrm{ppm}]=8.41-8.37\left(\mathrm{~m}, 1 \mathrm{H}, \mathrm{H}_{\mathrm{pyr}}\right)$, 8.23-8.21 (m, 2H, $\left.\mathrm{H}_{\mathrm{pyr}}\right), 7.35-7.31\left(\mathrm{~m}, 2 \mathrm{H}, \mathrm{H}_{\mathrm{PPh}}\right), 7.29-7.17$ (m, 14H, $\left.\mathrm{H}_{\mathrm{PPh}}+\mathrm{H}_{\mathrm{PYA}}\right), 7.10-7.04\left(\mathrm{~m}, 6 \mathrm{H}, \mathrm{H}_{\mathrm{PPh}}\right.$, 
$\left.\mathrm{H}_{\mathrm{PYA}}\right), 6.84-6.78$ (m, 4H, H $\left.\mathrm{HPh}_{\text {PP }} \mathrm{H}_{\mathrm{PYA}}\right), 3.65$ (s, 6H, N-CH $), 3.14-3.07$ (m, 1H, $\left.\mathrm{CH}_{2}\right), 3.05-3.02(\mathrm{~m}, 1 \mathrm{H}$, $\left.\mathrm{CH}_{2}\right), 2.99-2.94\left(\mathrm{~m}, 1 \mathrm{H}, \mathrm{CH}_{2}\right), 2.92-2.86\left(\mathrm{~m}, 1 \mathrm{H}, \mathrm{CH}_{2}\right), 2.35\left(\mathrm{~s}, 6 \mathrm{H}, \mathrm{C}_{\mathrm{PYA}}-\mathrm{CH}_{3}\right) .{ }^{13} \mathrm{C}\left\{{ }^{1} \mathrm{H}\right\} \mathrm{NMR}(75 \mathrm{MHz}$, $\left.\mathrm{CD}_{3} \mathrm{CN}, 298 \mathrm{~K}\right): \delta[\mathrm{ppm}]=171.55(\mathrm{C}=\mathrm{O}), 154.45\left(\mathrm{C}_{\mathrm{pyr}}\right), 150.81\left(\mathrm{C}_{\mathrm{PYA}}\right), 149.307\left(\mathrm{C}_{\mathrm{PYA}}\right), 143.70\left(\mathrm{CH}_{\mathrm{PYA}}\right)$, $143.08\left(\mathrm{CH}_{\mathrm{PYA}}\right), 139.49\left(\mathrm{CH}_{\mathrm{pyr}}\right), 136.42\left(\mathrm{~d},{ }^{1} J_{\mathrm{CP}}=36 \mathrm{~Hz}, \mathrm{C}_{\mathrm{PPh}}\right), 134.03\left(\mathrm{~d},{ }^{1} J_{\mathrm{CP}}=40 \mathrm{~Hz}, \mathrm{C}_{\mathrm{PPh}}\right), 131.21(\mathrm{~d}$, $\left.J_{\mathrm{CP}}=9.0 \mathrm{~Hz}, \mathrm{CH}_{\mathrm{PPh}}\right), 131.05\left(\mathrm{~d}, J_{\mathrm{CP}}=8.1 \mathrm{~Hz}, \mathrm{CH}_{\mathrm{PPh}}\right), 130.83\left(\mathrm{~d}, J_{\mathrm{CP}}=2.2 \mathrm{~Hz}, \mathrm{CH}_{\mathrm{PPh}}\right), 129.89\left(\mathrm{~d}, J_{\mathrm{CP}}=\right.$ $\left.8.8 \mathrm{~Hz}, \mathrm{CH}_{\mathrm{PPh}}\right), 129.68$ (d, $\left.J_{\mathrm{CP}}=2.3 \mathrm{~Hz}, \mathrm{CH}_{\mathrm{PPh}}\right), 129.29$ (d, $\left.J_{\mathrm{CP}}=8.7 \mathrm{~Hz}, \mathrm{CH}_{\mathrm{PPh}}\right), 129.14\left(\mathrm{CH}_{\mathrm{PYA}}\right), 126.83$ $\left(\mathrm{CH}_{\mathrm{pyr}}\right), 46.17\left(\mathrm{~N}-\mathrm{CH}_{3}\right), 25.79-25.25\left(\mathrm{~m}, \mathrm{CH}_{2 \mathrm{dppe}}\right), 23.97-23.54\left(\mathrm{~m}, \mathrm{CH}_{2 \mathrm{dppe}}\right), 19.42\left(\mathrm{C}_{\mathrm{PYA}}-\mathrm{CH}_{3}\right) .{ }^{31} \mathrm{P}\left\{{ }^{1} \mathrm{H}\right\}$ NMR $\left(162 \mathrm{MHz}, \mathrm{CD}_{3} \mathrm{CN}, 298 \mathrm{~K}\right): \delta[\mathrm{ppm}]=55.06\left(\mathrm{~d},{ }^{1} J_{\mathrm{PP}}=21 \mathrm{~Hz}, 1 \mathrm{P}, \mathrm{P}_{\mathrm{dppe}}\right), 54.47\left(\mathrm{~d},{ }^{1} J_{\mathrm{PP}}=21 \mathrm{~Hz}, 1 \mathrm{P}\right.$, $\mathrm{P}_{\text {dppe }}$ ), -144.60 (hept, $\left.{ }^{1} J_{\mathrm{PF}}=707 \mathrm{~Hz}, 2 \mathrm{P}, \mathrm{PF}_{6}\right)$. HR ESI-MS $\left(\mathrm{CH}_{3} \mathrm{CN}\right) \mathrm{m} / z$ calculated for $\left[\mathrm{M}-\mathrm{PF}_{6}-2 \mathrm{MeCN}^{+}\right.$ $=1020.1728$; found: 1020.1758 . Elemental Analysis: calculated for $\mathrm{C}_{49} \mathrm{H}_{48} \mathrm{~F}_{12} \mathrm{~N}_{6} \mathrm{O}_{2} \mathrm{P}_{4} \mathrm{Ru} \times \mathrm{CH}_{2} \mathrm{Cl}_{2}: \mathrm{C}: 46.52$; H: 3.90; N: 6.51; found: C: 47.10; H: 3.71; N: 6.41 .

Complex 4a. According to the general procedure starting from $\mathbf{L} 4$ (107 $\mathrm{mg}, 0.15 \mathrm{mmol})$, $\left[\mathrm{RuCl}_{2}(\mathrm{cym})\right]_{2}(47 \mathrm{mg}, 0.075 \mathrm{mmol})$ and $\mathrm{Na}_{2} \mathrm{CO}_{3}(48 \mathrm{mg}, 0.45 \mathrm{mmol})$ in $\mathrm{MeCN}$ (40 mL). Purification by gradient column chromatography $\left(\mathrm{Al}_{2} \mathrm{O}_{3} ; \mathrm{CH}_{2} \mathrm{Cl}_{2} / \mathrm{MeCN} 1: 1\right.$ to pure $\left.\mathrm{MeCN}\right)$ gave $4 \mathbf{a}$ as red powder $(90 \mathrm{mg}$, $65 \%) .{ }^{1} \mathrm{H}$ NMR $\left(300 \mathrm{MHz}, \mathrm{CD}_{3} \mathrm{CN}, 298 \mathrm{~K}\right): \delta[\mathrm{ppm}]=9.02\left(\mathrm{~d},{ }^{4} J_{\mathrm{HH}}=2.5 \mathrm{~Hz}, 2 \mathrm{H}, \mathrm{H}_{\mathrm{PYA}}\right), 8.40\left(\mathrm{dd},{ }^{3} J_{\mathrm{HH}}=\right.$ $\left.9.0 \mathrm{~Hz},{ }^{4} J_{\mathrm{HH}}=2.5 \mathrm{~Hz}, 2 \mathrm{H}, \mathrm{H}_{\mathrm{PYA}}\right), 8.11-8.06\left(\mathrm{~m}, 3 \mathrm{H}, \mathrm{H}_{\mathrm{pyr}}\right), 7.92\left(\mathrm{~d},{ }^{3} J_{\mathrm{HH}}=9.0 \mathrm{~Hz}, 2 \mathrm{H}, \mathrm{H}_{\mathrm{PYA}}\right), 4.29(\mathrm{~s}, 6 \mathrm{H}$, $\left.\mathrm{NCH}_{3}\right), 2.51$ (s, 3H, $\left.\mathrm{H}_{\mathrm{MeCN}(\text { equ })}\right), 2.13\left(\mathrm{~s}, 6 \mathrm{H}, \mathrm{H}_{\mathrm{MeCN}(\text { axial })}\right) .{ }^{13} \mathrm{C}\left\{{ }^{1} \mathrm{H}\right\} \mathrm{NMR}\left(75 \mathrm{MHz}, \mathrm{CD}_{3} \mathrm{CN}, 298 \mathrm{~K}\right): \delta[\mathrm{ppm}]$ $=171.21(\mathrm{C}=\mathrm{O}), 157.48\left(\mathrm{C}_{\mathrm{pyr}}\right), 151.07\left(\mathrm{C}_{\mathrm{pyr}}\right), 145.06\left(\mathrm{CH}_{\mathrm{pyr}}\right), 144.18\left(\mathrm{CH}_{\mathrm{pyr}}\right), 138.30\left(\mathrm{C}_{\mathrm{pyr}}\right), 137.16\left(\mathrm{CH}_{\mathrm{pyr}}\right)$, $129.12\left(\mathrm{CH}_{\text {pyr }}\right), 128.93(\mathrm{NCMe}), 126.66\left(\mathrm{CH}_{\mathrm{pyr}}\right), 124.94(\mathrm{NCMe}), 48.55\left(\mathrm{~N}-\mathrm{CH}_{3}\right), 4.62\left(\mathrm{NCCH}_{3}\right), 4.08$ $\left(\mathrm{NCCH}_{3}\right)$. HR ESI-MS $\left(\mathrm{CH}_{3} \mathrm{CN}\right) \mathrm{m} / z$ calculated for $\left[\mathrm{M}-\mathrm{PF}_{6}-\mathrm{MeCN}\right]^{+}=743.9814$; found: 743.9805 . Elemental Analysis: calculated for $\mathrm{C}_{25} \mathrm{H}_{24} \mathrm{Cl}_{2} \mathrm{~F}_{12} \mathrm{~N}_{8} \mathrm{O}_{2} \mathrm{P}_{2} \mathrm{Ru}$ C: $32.27 ; \mathrm{H}: 2.60 ; \mathrm{N}: 12.04$; found: C: 31.92; $\mathrm{H}$ : $2.61 ; \mathrm{N}: 11.85$.

Complex 5a. According to the general procedure starting from $\mathbf{L 5}$ (293 $\mathrm{mg}, 0.38 \mathrm{mmol}$ ), $\left[\mathrm{RuCl}_{2}(\mathrm{cym})\right]_{2}(116 \mathrm{mg}, 0.19 \mathrm{mmol})$ and $\mathrm{Na}_{2} \mathrm{CO}_{3}(120 \mathrm{mg}, 1.14 \mathrm{mmol})$ in $\mathrm{MeCN}(100 \mathrm{~mL})$. Purification by gradient column chromatography $\left(\mathrm{Al}_{2} \mathrm{O}_{3} ; \mathrm{CH}_{2} \mathrm{Cl}_{2} / \mathrm{MeCN} 1: 1\right.$ to pure $\left.\mathrm{MeCN}\right)$ gave 5a as red powder $(239 \mathrm{mg}, 63 \%) .{ }^{1} \mathrm{H}$ NMR $\left(300 \mathrm{MHz}, \mathrm{CD}_{3} \mathrm{CN}, 298 \mathrm{~K}\right): \delta[\mathrm{ppm}]=9.24\left(\mathrm{~d},{ }^{4} J_{\mathrm{HH}}=2.3 \mathrm{~Hz}, 2 \mathrm{H}, \mathrm{H}_{\mathrm{PYA}}\right), 8.51$ $\left(\mathrm{dd},{ }^{3} J_{\mathrm{HH}}=8.9 \mathrm{~Hz},{ }^{4} J_{\mathrm{HH}}=2.3 \mathrm{~Hz}, 2 \mathrm{H}, \mathrm{H}_{\mathrm{PYA}}\right), 8.26\left(\mathrm{~d},{ }^{3} J_{\mathrm{HH}}=8.9 \mathrm{~Hz}, 2 \mathrm{H}, \mathrm{H}_{\mathrm{PYA}}\right), 8.20-8.09\left(\mathrm{~m}, 3 \mathrm{H}, \mathrm{H}_{\mathrm{pyr}}\right)$, 4.42 (s, 6H, $\left.\mathrm{NCH}_{3}\right), 2.55$ (s, 3H, $\left.\mathrm{H}_{\mathrm{MeCN}(\text { equ })}\right), 2.14$ (s, 6H, $\left.\mathrm{H}_{\mathrm{MeCN}(\text { axial })}\right) .{ }^{13} \mathrm{C}\left\{{ }^{1} \mathrm{H}\right\} \mathrm{NMR}\left(75 \mathrm{MHz}, \mathrm{CD}_{3} \mathrm{CN}\right.$, $298 \mathrm{~K}): \delta[\mathrm{ppm}]=171.88(\mathrm{C}=\mathrm{O}), 157.12\left(\mathrm{C}_{\mathrm{pyr}}\right), 155.78\left(\mathrm{C}_{\mathrm{pyr}}\right), 148.35\left(\mathrm{CH}_{\mathrm{pyr}}\right), 141.44\left(\mathrm{CH}_{\mathrm{pyr}}\right), 137.48$ $\left(\mathrm{CH}_{\mathrm{pyr}}\right), 131.73\left(\mathrm{CF}_{3}, \mathrm{q},{ }^{1} J_{\mathrm{CF}}=36.7 \mathrm{~Hz}\right), 129.60(\mathrm{NCMe}), 127.74\left(\mathrm{C}_{\mathrm{pyr}}, \mathrm{q},{ }^{2} J_{\mathrm{CF}}=4.9 \mathrm{~Hz}\right), 127.41\left(\mathrm{CH}_{\mathrm{pyr}}\right)$, $125.46\left(\mathrm{CH}_{\mathrm{pyr}}\right), 122.02(\mathrm{NCMe}), 48.26\left(\mathrm{~N}-\mathrm{CH}_{3}\right), 4.76\left(\mathrm{NCCH}_{3}\right), 4.10\left(\mathrm{NCCH}_{3}\right)$. HR ESI-MS $\left(\mathrm{CH}_{3} \mathrm{CN}\right) \mathrm{m} / z$ calculated for $\left[\mathrm{M}-\mathrm{PF}_{6}-\mathrm{MeCN}\right]^{+}=812.0341$; found: 812.0371. Elemental Analysis: calculated for $\mathrm{C}_{27} \mathrm{H}_{24} \mathrm{~F}_{18} \mathrm{~N}_{8} \mathrm{O}_{2} \mathrm{P} 2 \mathrm{Ru}: \mathrm{C}: 32.51 ; \mathrm{H}: 2.43 ; \mathrm{N}: 11.23$; found: C: 32.44; H: 1.98; N: 10.71. 
General Procedure for Catalytic Transfer Hydrogenation. In a $20 \mathrm{~mL}$ pressure tube, a mixture of the complex, 2 molequiv $\mathrm{PPh}_{3}$ and hexamethylbenzene as internal standard were dissolved in $i \mathrm{PrOH}(5$ $\mathrm{mL}$ ). This solution was degassed with $\mathrm{N}_{2}$ for $10 \mathrm{~min}$. A degassed solution of the ketone substrate in $i \mathrm{PrOH}$ (1 M) was added via syringe and the solution was heated to $70{ }^{\circ} \mathrm{C}$ for $10 \mathrm{~min}$. The catalytic reaction was started by injection of $\mathrm{KOH}\left(2 \mathrm{M}\right.$ solution in $\left.\mathrm{H}_{2} \mathrm{O}\right)$ and heated to reflux in an oil bath $\left(110{ }^{\circ} \mathrm{C}\right)$. Aliquots (ca. $0.1 \mathrm{ml}$ ) were taken at set times, and quenched by dissolving into $\mathrm{CDCl}_{3}$ for ${ }^{1} \mathrm{H} \mathrm{NMR}$ analysis. Conversions were determined relative to hexamethylbenzene as internal standard and correspond to spectroscopic yields.

Crystal structure determination. Suitable single crystals of $\mathbf{1 a}$ and $\mathbf{5 a}$ were mounted in air at ambient conditions and measured on an Oxford Diffraction SuperNova area-detector diffractometer ${ }^{[57]}$ using mirror optics monochromated Mo K $\alpha$ radiation $(\lambda=0.71073 \AA)$ and Al filtered. ${ }^{[58]}$ The unit cell constants and an orientation matrix for data collection were obtained from a least-squares refinement of the setting angles of reflections. Data reduction was performed using the CrysAlisPro ${ }^{[57]}$ program. The intensities were corrected for Lorentz and polarization effects, and a numerical absorption correction based on Gaussian integration over a multifaceted crystal model was applied. Data collection and refinement parameters are given in the SI. The structure was solved by direct methods using SHELXT ${ }^{[59]}$, which revealed the positions of all non-hydrogen atoms of the title compounds. The non-hydrogen atoms were refined anisotropically. All H-atoms were placed in geometrically calculated positions and refined using a riding model where each $\mathrm{H}$-atom was assigned a fixed isotropic displacement parameter with a value equal to 1.2Ueq of its parent atom (1.5Ueq for methyl groups and water). Refinement of the structure was carried out on $F^{2}$ using fullmatrix least-squares procedures, which minimized the function $\Sigma \mathrm{w}\left(\mathrm{F}_{\mathrm{o}}{ }^{2}-\mathrm{F}_{\mathrm{c}}{ }^{2}\right)^{2}$. The weighting scheme was based on counting statistics and included a factor to downweight the intense reflections. All calculations were performed using the SHELXL-2014/7 ${ }^{[60]}$ program in OLEX2. ${ }^{[61]}$ The crystal of 1a contains two cocrystallized acetonitrile solvent molecules and 0.173 co-crystallized water molecules per asymmetric unit. The crystal of 5a contains one co-crystallized acetonitrile solvent molecule per asymmetric unit. Further crystallographic details are compiled in Tables S4 and S5. Crystallographic data for all structures have been deposited with the Cambridge Crystallographic Data Centre (CCDC) as supplementary publication numbers 1986022 (1a) and 1986021 (5a).

\section{Acknowledgements}

We thank the Swiss National Science Foundation (200020_182663) and the European Research Council (CoG 615653) for generous financial support and the Swiss European Mobility Programme for a visiting fellowship to D.A.H. 
Supporting Information: NMR spectra of all compounds, cyclic voltammetry measurements of complexes 2a and 4a, UV-vis spectra of complexes 1a-5a, catalytic transfer hydrogenation experiments, and crystallographic details.

\section{References}

[1] J. R. Khusnutdinova, D. Milstein, Angew. Chem. Int. Ed. 2015, 54, 12236-12273.

[2] C. Gunanathan, D. Milstein, Chem. Rev. 2014, 114, 12024-12087.

[3] C. Gunanathan, D. Milstein, Acc. Chem. Res. 2011, 44, 588-602.

[4] L. Alig, M. Fritz, S. Schneider, Chem. Rev. 2019, 119, 2681-2751.

[5] V. Lyaskovskyy, B. De Bruin, ACS Catal. 2012, 2, 270-279.

[6] L. A. Berben, B. De Bruin, A. F. Heyduk, Chem. Commun. 2015, 51, 1553-1554.

[7] J. I. Van Der Vlugt, Eur. J. Inorg. Chem. 2012, 363-375.

[8] D. L. J. Broere, R. Plessius, J. I. Van Der Vlugt, Chem. Soc. Rev. 2015, 44, 6886-6915.

[9] D. Bourissou, O. Guerret, F. P. Gabbaï, G. Bertrand, Chem. Rev. 2000, 100, 39-91.

[10] M. N. Hopkinson, C. Richter, M. Schedler, F. Glorius Nature 2014, 510, 485-496.

[11] E. Peris, Chem. Rev. 2018, 118, 9988-10031.

[12] C. A. Smith, M. R. Narouz, P. A. Lummis, I. Singh, A. Nazemi, C. H. Li, C. M. Crudden, Chem. Rev. 2019, 119, 4986-5056.

[13] Á. Vivancos, C. Segarra, M. Albrecht, Chem. Rev. 2018, 118, 9493-9586.

[14] O. Schuster, L. Yang, H. G. Raubenheimer, M. Albrecht, Chem. Rev. 2009, 109, 3445-3478.

[15] N. Kuhn, H. Bohnen, J. Kreutzberg, D. Bläser, R. Boese, J. Chem. Soc., Chem. Commun. 1993, $1136-1137$.

[16] S. M. Ibrahim Al-Rafia, A. C. Malcolm, S. K. Liew, M. J. Ferguson, R. McDonald, E. Rivard, Chem. Commun. 2011, 47, 6987-6989.

[17] R. S. Ghadwal, S. O. Reichmann, F. Engelhardt, D. M. Andrada, G. Frenking, Chem. Commun. 2013, 49, 9440-9442.

[18] S. Naumann, Chem. Commun. 2019, 55, 11658-11670. 
[19] M. M. D. Roy, E. Rivard, Acc. Chem. Res. 2017, 50, 2017-2025.

[20] E. Rivard, Chem. Soc. Rev. 2016, 45, 989-1003.

[21] L. Benhamou, E. Chardon, G. Lavigne, S. Bellemin-Laponnaz, V. César, Chem. Rev. 2011, 111, $2705-2733$.

[22] H. Bruns, M. Patil, J. Carreras, A. Vezquez, W. Thiel, R. Goddard, M. Alcarazo, Angew. Chem. Int. Ed. 2010, 49, 3680-3683.

[23] Á. Kozma, G. Gopakumar, C. Farès, W. Thiel, M. Alcarazo, Chem. Eur. J. 2013, 19, 3542-3546.

[24] P. D. W. Boyd, L. J. Wright, M. N. Zafar, Inorg. Chem. 2011, 50, 10522-10524.

[25] M. E. Doster, S. A. Johnson, Angew. Chem. Int. Ed. 2009, 48, 2185-2187.

[26] Q. Shi, R. J. Thatcher, J. Slattery, P. S. Sauari, A. C. Whitwood, P. C. McGowan, R. E. Douthwaite, Chem. Eur. J. 2009, 15, 11346-11360.

[27] J. Slattery, R. J. Thatcher, Q. Shi, R. E. Douthwaite, Pure Appl. Chem. 2010, 82, 1663-1671.

[28] K. F. Donnelly, C. Segarra, L.-X. Shao, R. Suen, H. Müller-Bunz, M. Albrecht, Organometallics 2015, 34, 4076-4084.

[29] M. Navarro, M. Li, H. Müller-Bunz, S. Bernhard, M. Albrecht, Chem. Eur. J. 2016, 22, 6740-6745.

[30] V. Leigh, D. J. Carleton, J. Olguin, H. Mueller-Bunz, L. J. Wright, M. Albrecht, Inorg. Chem. 2014, $53,8054-8060$.

[31] M. Navarro, M. Li, S. Bernhard, M. Albrecht, Dalton Trans. 2017, 47, 659-662.

[32] M. Navarro, C. A. Smith, M. Albrecht, Inorg. Chem. 2017, 56, 11688-11701.

[33] M. Navarro, C. A. Smith, M. Li, S. Bernhard, M. Albrecht, Chem. Eur. J. 2018, 24, 6386-6398.

[34] M. Navarro, V. Rosar, T. Montini, B. Milani, M. Albrecht, Organometallics 2018, 37, 3619-3630.

[35] P. Melle, Y. Manoharan, M. Albrecht, Inorg. Chem. 2018, 57, 11761-11774.

[36] P. Melle, M. Albrecht, Chimia 2019, 73, 299-303.

[37] C. M. A. Muller, M. V Babak, M. Kubanik, M. Hanif, S. M. F. Jamieson, C. G. Hartinger, L. J. Wright, Inorg. Chim. Acta 2016, 450, 124-130.

[38] A. Dorazco-González, H. Höpfl, F. Medrano, A. K. Yatsimirsky, J. Org. Chem. 2010, 75, 22592273.

[39] R. J. Thatcher, D. G. Johnson, J. M. Slattery, R. E. Douthwaite, Chem. Eur. J. 2012, 18, 4329-4336. 
[40] C. Hansch, A. Leo, R. W. Taft, Chem. Rev. 1991, 91, 165-195.

[41] D. Wang, D. Astruc, Chem. Rev. 2015, 115, 6621-6686.

[42] B. J. Coe, S. J. Glenwright, Coord. Chem. Rev. 2000, 203, 5-80.

[43] M. Renom-Carrasco, L. Lefort, Chem. Soc. Rev. 2018, 47, 5038-5060.

[44] J. G. de Vries, A. H. M. de Vries, Eur. J. Org. Chem. 2003, 799-811.

[45] M. R. Friedfeld, H. Zhong, R. T. Ruck, M. Shevlin, P. J. Chirik, Science 2018, 360, 888-893.

[46] C. Tai, J. Pitts, J. C. Linehan, A. D. Main, P. Munshi, P. G. Jessop, Inorg. Chem. 2002, 41, 16061614.

[47] J. Louie, R. H. Grubbs, Angew. Chem. Int. Ed. 2001, 40, 247-249.

[48] W. Zuo, A. J. Lough, Y. F. Li, R. H. Morris, Science 2013, 342, 1080-1084.

[49] S. Zhang, S. Baldino, W. Baratta, Organometallics 2013, 32, 5299-5304.

[50] P. Singh, A. K. Singh, Organometallics 2010, 29, 6433-6442.

[51] M. Poyatos, A. Mata, E. Falomir, R. H. Crabtree, E. Peris, Organometallics 2003, 22, 1110-1114.

[52] C. D. Nielsen, J. Bures, Chem. Sci. 2019, 10, 348-353.

[53] J. Bures, Angew. Chem. Int. Ed. 2016, 55, 2028-2031.

[54] J. Bures, Angew. Chem. Int. Ed. 2016, 55, 16084-16087.

[55] S. E. Clapham, A. Hadzovic, R. H. Morris, Coord. Chem. Rev. 2004, 248, 2201-2237.

[56] N. G. Connelly, W. E. Geiger, Chem. Rev. 1996, 96, 877-910.

[57] Oxford Diffraction Ltd., Ed., CrysAlisPro, Yarnton, Oxfordshire, U.K., 2010.

[58] P. Macchi, H.-B. Bürgi, A. S. Chimpri, J. Hauser, Z. Gál, J. Appl. Cryst. 2011, 44, 763-771.

[59] G. M. Sheldrick, Acta Crystallogr. C 2015, 71, 3-8.

[60] G. M. Sheldrick, Acta Crystallogr. A 2015, 71, 3-8.

[61] O. V. Dolomanov, L. J. Bourhis, R. J. Gildea, J. A. K. Howard, H. Puschmann, J. Appl. Cryst. 2009, 42, 339-341. 